\title{
Auditor Lobbying on Accounting Standards
}

\section{Citation}

Allen, Abigail, Karthik Ramanna, and Sugata Roychowdhury. "Auditor Lobbying on Accounting Standards." Harvard Business School Working Paper, No. 15-055, December 2014.

\section{Permanent link}

http://nrs.harvard.edu/urn-3:HUL.InstRepos:13688359

\section{Terms of Use}

This article was downloaded from Harvard University's DASH repository, and is made available under the terms and conditions applicable to Open Access Policy Articles, as set forth at http:// nrs.harvard.edu/urn-3:HUL.InstRepos:dash.current.terms-of-use\#OAP

\section{Share Your Story}

The Harvard community has made this article openly available.

Please share how this access benefits you. Submit a story.

Accessibility 

H A R V A R D
B U S I N E S S
S C H O O L

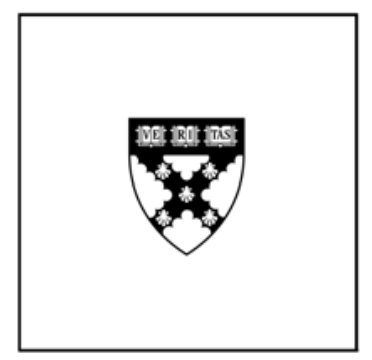

\title{
Auditor Lobbying on Accounting Standards
}

\author{
Abigail Allen \\ Karthik Ramanna \\ Sugata Roychowdhury
}

\section{Working Paper}

15-055

December 22, 2014 


\title{
Auditor lobbying on accounting standards
}

\author{
Abigail Allen \\ Harvard Business School \\ aallen@hbs.edu \\ Karthik Ramanna* \\ Harvard Business School \\ kramanna@hbs.edu \\ Sugata Roychowdhury \\ Boston College \\ sugata.roychowdhury@bc.edu
}

This draft: December 22, 2014

\begin{abstract}
We examine how Big $\mathrm{N}$ auditors' changing incentives impact their comment-letter lobbying on U.S. GAAP over the first thirty-four years of the FASB (1973-2006). We examine the influence of auditors' lobbying incentives arising from three basic factors: managing expected litigation and regulatory costs; catering to clients' preferences for flexibility in GAAP; and being conceptually aligned with the FASB, particularly on the use of fair values in accounting. We find evidence that auditor lobbying is driven by prevailing standards of litigation and regulatory scrutiny and by support for fair-value accounting. But we find no evidence that catering to clients' preferences for flexibility in GAAP drives auditor lobbying. Broadly, our paper offers the first large-sample descriptive analysis of the role of Big $\mathrm{N}$ auditors in the accounting standard-setting process.
\end{abstract}

Keywords: Auditors, FASB, GAAP, lobbying

JEL Codes: D72, G18, M41, M42, M48

\footnotetext{
* Corresponding author: Morgan Hall 389, Boston, MA, 02163. Phone: +1-617-384-5739. We thank Judson Caskey, Jeff Cohen, Dain Donelson, Jere Francis, Amy Hutton, Richard Macve, John McInnis, Jaime Schmidt, Susan Shu, Ewa Sletten, Eugene Soltes, Ross Watts, Jerry Zimmerman and workshop participants at Harvard Business School, London School of Economics, University of Missouri, University of Rochester, University of Texas at Austin, the 2013 Boston Area Research Colloquium, the 2013 Harvard IMO Conference, and the 2014 AAA Western Region Conference for helpful comments; John Sheridan for research assistance; and the Financial Accounting Foundation for help in sourcing data. This paper is based on a previous unpublished manuscript titled "The auditing oligopoly and lobbying on accounting standards.”
} 


\section{Introduction}

Corporate accounting standards are an important basis for the measurement of firm and managerial performance and for the stewardship of corporate assets in a market economy. The political process underlying corporate accounting standard setting is a critical area of study for accounting researchers (e.g., Kothari, Ramanna, and Skinner, 2010). Understanding the process that culminates with the creation of accounting standards can provide insights into both their procedural legitimacy and how they will eventually be used. In this paper, our goal is to advance the literature on the role of auditors in the accounting standard-setting process through a longitudinal study of the varying nature of auditor comment-letter lobbying at the Financial Accounting Standards Board (FASB).

Over the past several years, a number of empirical studies have explored various dimensions of the political process in corporate accounting standard setting in the United States. These include studies of the role of corporate lobbying (e.g., Watts and Zimmerman, 1978; Francis, 1987; Deakin, 1989; Dechow, Hutton, and Sloan, 1996; Ramanna, 2008), the role of the standard setters at the Financial Accounting Standards Board (FASB) (e.g., Allen and Ramanna, 2013; Chakravarthy, 2014; Jiang, Wang, and Xie, 2014), the role of agenda setting at the FASB (Leftwich, 1995; Allen, 2013), and the role of congressional involvement in accounting standard setting (Farber, Johnson, and Petroni, 2007; Ramanna, 2008).

Auditors play a crucial role in the functioning of capital markets by serving as independent agents who attest that companies, in preparing their financial reports, conform to generally accepted accounting principles (GAAP). However, auditors' role is hardly restricted to scrutinizing firms' financial statements. Rather, auditors participate in the standard-setting process via comment-letter lobbying and thus influence financial reporting standards at their very 
genesis (e.g., Watts and Zimmerman, 1986; Zeff, 2003a, b). Empirical evidence on the role of auditors in this political process is limited. In a recent review of empirical research on standard setting, Gipper, Lombardi, and Skinner (2013) note that with the exception of this paper there has been no empirical work focused on the role of auditors in accounting's political process in the United States since research on the subject in the early 1980s (e.g., Watts and Zimmerman, 1982; Puro, 1984). ${ }^{1}$

Auditors' opinions in comment letters are likely to be shaped not just by the nature of the proposed standards but also by their own prevailing incentives. Indeed, Watts and Zimmerman (1982) and Puro (1984) find evidence consistent with opportunistic auditor lobbying in the FASB due process. Both studies rely on an analysis of comment letters filed by auditors on a limited sample of six FASB proposals each. We contribute to the literature via a systematic characterization of auditors' incentives and an examination of how those incentives influence auditor lobbying across nearly every financial reporting standard issued from 1973 through 2006.

We focus on the group of auditors most likely to consistently lobby across standards and over time: the "Big N" firms. Since at least the inception of the FASB in 1973, the audit market in the U.S. has functioned as an oligopoly, with a few large firms providing audit services for the vast majority of public companies. The number of audit firms in this oligopoly - the Big $\mathrm{N}$ - has varied from eight through the 1980s to four by the early 2000s (see Appendix 1). The Big $\mathrm{N}$ auditors have consistently represented an influential and economically significant fraction of

\footnotetext{
${ }^{1}$ Mian and Smith (1990) study auditor lobbying on SFAS 94 (mandated changes regarding consolidation). However, their analysis of auditor lobbying is part of a broader effort to understand client-firm incentives in lobbying on SFAS 94 , and much of their auditor lobbying analysis is univariate in nature.
} 
auditing activity in the United States, and a study of their lobbying behavior can generate meaningful insights.

We identify three broad, non-mutually exclusive economic factors that can shape auditors' lobbying incentives over time. First, given the fiduciary nature of the auditors' responsibilities toward capital market participants, we expect disciplinary forces such as litigation and regulation to be important in shaping auditors' incentives (see, e.g., St. Pierre and Anderson, 1984; Kothari, Lys, Smith, and Watts, 1988; Lys and Watts, 1994; and Dechow, Sloan, and Sweeny, 1996). Second, since auditors are dependent on their clients for revenue generation, clients' preferences are likely to be a significant influence on Big $\mathrm{N}$ auditor lobbying (see, e.g., Puro, 1984). In particular we are interested in testing whether auditors lobby for more flexible standards in the interest of their clients. Third, Big $\mathrm{N}$ auditor lobbying can also reflect their desire to support the FASB in its own conceptual agenda, particularly when that agenda does not directly contradict the auditors’ own incentives. Watts and Zimmerman (1986) note that auditors have incentives to support the FASB on accounting matters so as to be able to continue to effect wealth transfers through accounting regulation.

Because we seek to compare auditor lobbying over a long time series spanning a number of different accounting issues, we require a common dimension of proposed standards that auditors are likely to comment on consistently. Additionally, we require that auditor lobbying along this common dimension varies with auditors' incentives in a predictable manner. With these objectives in mind, we focus on auditor lobbying over the "reliability" of proposed accounting standards. Reliability is a "fundamental qualitative characteristic" of accounting, as 
identified by the FASB in its own original conceptual framework, which was in effect through most of our sample period (FASB, 1980). ${ }^{2}$ Numerous basic accounting textbooks (e.g., Stickney, Weil, Schipper, and Francis 2010) recognize reliability as a central accounting concept. Reliability limits managers' discretion in accounting choice to reporting methods that are verifiable, while additionally being representationally faithful. More reliable standards demand objectivity in accounting estimates, facilitating audits and potentially reducing litigation and regulatory costs by restricting client firms' flexibility in accounting choices and hence their ability to misreport. Thus, depending on the relative strength of their incentives to promote reliability versus flexibility, auditors are likely to vary the extent to which they emphasize reliability while commenting on proposed standards. Our use of reliability is not to suggest that it is the sole focus of auditors or that other primitive accounting characteristics such as "relevance" or "comparability" could not also be used in an empirical study such as ours. Rather, we simply note that reliability matters to both accounting and auditing, and auditor lobbying along this metric is predictably influenced by their incentives.

Across our time series, we examine how the Big $\mathrm{N}$ auditors' propensity to express concerns about decreased reliability in proposed accounting standards varies with the various incentives conjectured to have influenced the nature of Big $\mathrm{N}$ auditor lobbying (such as prevailing litigation and regulatory regimes, client preferences for flexibility, etc.). But to do so in a regression setting, we must control for the possibility that auditors' propensity to highlight decreased reliability in proposed standards is driven by substantive issues with the standards

\footnotetext{
${ }^{2}$ The FASB in 2010 modified its conceptual framework, deemphasizing "reliability" as a fundamental accounting characteristic in favor of "representational faithfulness." Since this change went into effect after our sample period (1973-2006), we use "reliability" not "representational faithfulness" in our analyses.
} 
themselves. Thus, we generate a benchmark measure of decreased reliability that represents, in principle, the "true" concern over decreased reliability on a given proposed standard. This benchmark is based on evaluations of the proposed standards by two highly experienced research assistants blind to the study's objective (the data are from Allen and Ramanna, 2013). ${ }^{3}$ The changing correlations between the Big $\mathrm{N}$ auditors' mentions of decreased reliability and this benchmark provide a measure of the auditors' changing incentives. We examine how these correlations vary across the various factors conjectured to have influenced the nature of Big $\mathrm{N}$ auditor lobbying over the thirty-four years in our sample.

We first investigate whether the Big $\mathrm{N}$ auditors’ lobbying varies in response to changing litigation and regulatory exposure. We find that the proportion of lawsuits against auditors and the level of SEC enforcement on accounting and auditing issues are predictably associated with the nature of auditor lobbying. In periods with higher incidence of lawsuits and more intense levels of SEC enforcement, the Big $\mathrm{N}$ auditors are more likely to express concerns about decreased reliability. These results are consistent with a large body of research on auditors mitigating their litigation risk (see DeFond and Zhang, 2014, for a review). But, while this research has conjectured that auditors attenuate their litigation risk via lobbying activities, DeFond and Zhang's (2014) review suggests that there is little direct empirical evidence to this point. Instead, the evidence on auditor lobbying is either anecdotal or implied from an analysis of the economic consequences of regulatory changes (e.g., Geiger and Raghunandan, 2001; Lee and Mande, 2003). Thus, our study also adds to the literature by providing direct large-sample evidence of auditor lobbying to mitigate litigation risk.

\footnotetext{
${ }^{3}$ Our use of this benchmark presumes no systematic hindsight bias in research assistants' evaluations of exposure drafts.
} 
We next investigate whether Big $\mathrm{N}$ auditors lobby for greater flexibility in standards in the interest of their clients. In certain circumstances - e.g., high expected litigation - clients may desire reduced accounting flexibility. However, the literature points out that clients often prefer standards that allow flexibility to choose the most appropriate reporting method for a given transaction (e.g., Watts and Zimmerman, 1986; Zeff, 2003; Folsom, Hribar, Mergenthaler, Peterson, 2013). Using firm-level characteristics that capture clients’ preferences for flexibility, we find no evidence that such preferences influence auditor lobbying. Further, we identify exposure drafts where client interest in the final outcome is likely to be particularly high. We focus on proposed standards that are specific to an industry (where client interests are more likely to be concentrated) and standards that witnessed high lobbying intensity. Despite this effort to home in on settings characterized by high client interest, we observe no evidence that auditor lobbying is influenced by client preferences for flexibility. This finding is consistent with earlier conclusions by Watts and Zimmerman (1982) and Puro (1984) that auditors' lobbying behavior is driven more by their own interests than those of their clients.

We also investigate the extent to which Big $\mathrm{N}$ auditor lobbying can be explained by changing trends in the priorities of standard setters. In particular, since the 1990s, the proportion of accounting standards using fair-value methodologies has increased. This increase represents an agenda shift toward fair-value accounting at the FASB (see, e.g., Ramanna, 2014, for citations to numerous FASB documents on the shift to fair values). To the extent that this fair-value agenda does not detract from the Big $\mathrm{N}$ auditors' own incentives, the auditors may support the agenda. Doing so helps them extract rents from the FASB on other issues (Watts and Zimmerman, 1986). We examine how Big $\mathrm{N}$ auditor lobbying over decreased reliability has varied with the proposed use of fair-values methodologies in accounting. Relatedly, we examine 
how Big $\mathrm{N}$ auditor lobbying has varied with the increased proportion of FASB members from asset management and investment banking because Allen and Ramanna (2013) report that the growing proportion of FASB members from these industries is associated with the growth of fair-value accounting. We find that the Big $\mathrm{N}$ auditors are less prone to express concerns about decreased reliability in proposed standards (relative to the benchmark) in both of these cases.

Finally, we investigate how auditor lobbying varies across broad regime shifts that potentially alter the relative weight that auditors place on their various incentives. We find that the changing legal principles on auditor liability in the United States affect Big N auditors' lobbying over decreased reliability in predictable ways. Specifically, in regimes in which legal precedents offer a lower bar for auditor liability, the Big $\mathrm{N}$ auditors exhibit a more pronounced tendency to express concerns regarding decreased reliability (conditioned on the benchmark). We also consider the possibility that the changing nature of the Big $\mathrm{N}$ auditor oligopoly itself e.g., eight versus four Big $\mathrm{N}$ firms - could have influenced auditor lobbying. Fewer Big $\mathrm{N}$ audit firms imply a different competitive dynamic vis-à-vis clients and regulators. We find evidence that the changing nature of the Big $\mathrm{N}$ auditor oligopoly - in particular, the tightening of the oligopoly through a decrease in the number of Big $\mathrm{N}$ players - is associated with the auditors' lobbying behavior. As the oligopoly tightens, surviving auditors exhibit a heightened tendency to express concern about decreased reliability (conditioned on the benchmark). This finding is consistent with the political costs hypothesis - the fewer surviving Big $\mathrm{N}$ auditors are more visible targets for both regulatory action and litigation and thus prefer enhanced reliability in accounting standards. The finding is inconsistent with claims that the Big $\mathrm{N}$ auditors perceive themselves as "too big to fail," which would predict the Big $\mathrm{N}$ auditors are at best agnostic with respect to decreased reliability in proposed standards. 
Broadly, the evidence in this paper provides a window into the nature of auditor lobbying in U.S. accounting standard setting, particularly how such lobbying has varied across numerous factors that are likely to have affected the auditing industry over the past forty years. We caution that the nature of our tests prevents us from making causal statements in this regard. Nevertheless, given that it has been nearly thirty years since a focused empirical study of auditor lobbying in U.S. GAAP and given the centrality of Big $\mathrm{N}$ auditors to accounting and capital markets, we submit that the descriptive evidence in this paper is an important added insight into accounting's political economy. Collectively, our evidence suggests that the auditors' own incentives play a prominent role in their lobbying activities on U.S. GAAP.

The remainder of this paper is organized as follows. Section 2 explores the economic factors likely to shape auditors' lobbying on proposed accounting standards, in particular, their lobbying on decreased reliability in the proposed standards. Section 3 describes the data and research design. Section 4 presents and interprets the results. Section 5 concludes with a discussion of the study's implications.

\section{Factors influencing auditor lobbying on reliability}

As noted in the introduction, we identify three broad economic factors that we expect will shape Big $\mathrm{N}$ auditors' incentives over time, particularly their incentives when lobbying the FASB on proposed accounting standards. In this section, we discuss these factors and explore their likely impact on Big $\mathrm{N}$ auditor comments about decreased reliability in proposed accounting standards. An implicit assumption is that the auditors lobby in their self-interest, which is consistent with Kinney's (1986) findings on lobbying at the Auditing Standards Board. Of course, auditors' lobbying behavior may very well be "neutral"; that is, their comments are 
driven entirely by the nature of the proposed standards. Our empirical analysis, discussed in the following section, controls for this possibility.

The first factor we study arises from the certification role that auditors play in capital markets. Auditors certify to users of corporate financial statements that financial reports are prepared in accordance with GAAP and other relevant statutory requirements and that such reports disclose relevant material information. This certification is offered under penalty of varying civil and criminal liabilities and under regulatory scrutiny by the government. Capital market constituents such as investors and regulators can subject auditors (and their clients) to significant penalties for negligence, misrepresentation, and fraud. The penalties include the litigation costs of class-action lawsuits by the investing community (e.g., Kothari et al., 1988; Lys and Watts 1994) and the political costs of enhanced scrutiny, fines, and imprisonment by regulatory authorities (e.g., Feroz, Park, and Pastena, 1991; Karpoff, Lee, and Martin, 2008; Files 2012). To mitigate litigation and political costs, auditors are likely to prefer accounting standards that allow less room for client discretion.

Accounting choices of clients are easier to audit when they are verifiable, making misinterpretations and improper implementation of the standards less probable ex ante. Further, verifiable accounting choices that are questioned in securities class-action or regulatory action may be more defensible ex post because they have met ex ante objectivity standards (e.g., Ramanna and Watts, 2012). Consistent with this intuition, Donelson, McInnis, and Mergenthaler (2012) document that securities class-action involving accounting rules that are less flexible and provide more guidance for implementation are associated with fewer incidences of litigation. The above arguments suggest that expected litigation and regulatory costs will, ceteris paribus, incentivize Big $\mathrm{N}$ auditors to seek (oppose) accounting rules that enhance (decrease) verifiability 
and objectivity, key elements of reliability as defined by the FASB in its original conceptual framework. ${ }^{4}$ Thus, in our time series, we expect under conditions where expected litigation and regulatory costs are particularly high, Big $\mathrm{N}$ auditors are more likely to emphasize concerns about decreased reliability in their lobbying.

The second factor likely to shape Big $\mathrm{N}$ auditor incentives when lobbying the FASB is the preferences of their clients. In a competitive equilibrium, an auditor's wealth is eventually dependent on that of its clients. In practice, the management and boards of the client companies make the decisions on hiring and firing auditors, so the latter have an incentive to keep these decision makers at client companies happy (e.g., Watts and Zimmerman 1982; Puro 1984).

Clients typically encounter a heterogeneous range of transactions in their operations. Ceteris paribus, they would thus prefer standards that allow them flexibility to choose the most appropriate reporting method for a given transaction, conditional on the economic circumstances underlying that transaction. Zeff (2003a) points to a manifest demand from clients for accounting flexibility in reporting standards as far back as the 1960s. The intense lobbying that preceded APBO 4 on the treatment of investment tax credits (1963) is one such example. Another example would be the "ferocity" (Zeff, 2003a) of lobbying by US corporations against Accounting Principles Board proposals to restrict flexibility in accounting choice in business combinations and the treatment of goodwill (1968-1970). Clients' preference for greater choice was also evident in their activism in favor of flexibility in the accounting treatment of stock option compensation (1994-95). A recent example of clients' demand for flexibility is Apple's

\footnotetext{
4 "Reliability" is a term frequently discussed in comment letters while its components such as "verifiability" and "objectivity" are referenced less frequently. For example, the raw incidence of reliab* across Big $\mathrm{N}$ letters in our sample is 137, while that of verifiab* is 32 .
} 
successful lobbying for a revision of accounting standards that permits the company to recognize a discretionary (and larger-than-before) fraction of the revenue stream from an iPhone at the point of sale (Brochet, Palepu, and Barley 2011).

More broadly, Watts and Zimmerman (1986) argue that managers choose accounting methods to suit their firms' contracting, information, regulatory, and tax environments. Kothari et al. (2010, 277) argue that "accounting is of strategic importance rather than a compliance tool," so there are "rents to be earned” by firms from customizing their accounting metrics. Both studies provide arguments suggesting that firms, on average, would prefer greater accounting flexibility.

It is entirely possible that in certain circumstances, e.g., to harm competitors or to forestall high expected litigation and regulatory costs, clients would desire reduced accounting flexibility. In such instances, clients' preferences would align with auditors' incentives arising out of litigation and regulatory risk. But in our second set of tests, we are interested in investigating whether incentives to cater to their clients' interests motivate Big $\mathrm{N}$ auditors to lobby for more flexible standards. Such flexibility is facilitated by accounting discretion, which can come at the expense of objectivity, a key component of reliability. Thus, ceteris paribus, clients’ preferences for flexibility in accounting standards can provide Big $\mathrm{N}$ auditors incentives to support accounting rules that can compromise reliability. In our time series, we expect that the Big $\mathrm{N}$ are more likely to de-emphasize concerns about decreased reliability in cases characterized by a higher likelihood of catering to their clients' preferences for flexibility.

A third factor possibly shaping Big $\mathrm{N}$ auditors' lobbying incentives is their desire to support the FASB in its own conceptual agenda. A large literature in political science studying 
the relation between firms and politicians notes that firms successful in advancing their interests in the political process tend to be "ideologically aligned" with the politician decision-makers in that process (e.g., Kalt and Zupan, 1984; Snyder, 1992). A similar situation could characterize the political process at the FASB - that is, Big $\mathrm{N}$ auditors are more successful in securing accounting standards that suit their interests when they are conceptually aligned with the FASB. In this vein, Watts and Zimmerman (1986) note that auditors have incentives to support the FASB on accounting matters so as to be able to continue to effect wealth transfers through accounting regulation. Relatedly, Mian and Smith (1990, p. 256) note that auditors "might reason that if the FASB fails, whatever succeeds it (some governmental body such as the SEC) is likely to be worse for the auditing industry." Of course, the auditors' desire to support the FASB in its agenda is likely to be limited to cases where that agenda does not directly conflict with the auditors' own incentives (e.g., mitigating litigation risk or satisfying client preferences for flexibility, as discussed earlier).

One of the major agenda items at the FASB over our sample period - particularly since the early 1990s - has been the growth of fair-value accounting. U.S. GAAP rules have over time adopted more fair-value-based methodologies at the expense of the traditional historical-cost approach. Allen and Ramanna (2013) find that this growth in fair-value accounting is associated with the growing proportion of FASB members with backgrounds in financial services (investment banking and investment management). Relatedly, Chakravarthy (2014) finds evidence of greater "ideological homogenization" around fair-value accounting among FASB members since the 1990s.

At least anecdotally, the Big $\mathrm{N}$ auditors have been supportive of - or at least have not been opposed to - this agenda shift toward fair-value accounting. For example, in 2006, all of the 
Big 4 audit firms wrote comment letters supportive of SFAS 159 - "The Fair Value Option for Financial Assets and Liabilities” - which relies considerably on fair-value accounting. The Big N auditors' position on fair-value accounting perhaps reflects that their own liability for fair-value estimates is limited by the auditing standard SAS 101, Auditing Fair Value Measurements and Disclosures. In particular, SAS 101 suggests that corporate managers, and not their auditors, are "responsible for making the fair value measurements and disclosures included in the financial statements" and that auditors are "not responsible for predicting future conditions" required of fair-value estimates. ${ }^{5}$ Based on the arguments above, we examine whether Big $\mathrm{N}$ auditors are more likely to support the FASB in its agenda to promulgate fair-value accounting standards. Doing so might help the auditors to extract rents from the FASB on other accounting matters (Watts and Zimmerman, 1986; Mian and Smith, 1990).

Fair-value estimates, particularly when generated absent corroborating evidence from liquid, thickly-traded markets, are difficult to verify. In these cases, the use of fair-value estimates can decrease reliability (e.g., Watts, 2003). If auditors are indeed supportive of fairvalue accounting, they are likely to de-emphasize concerns about decreased reliability when lobbying on proposed standards that advance fair values. Relatedly, if fair-value proposals are associated with FASB members from financial-services backgrounds (as Allen and Ramanna, 2013, find), Big $\mathrm{N}$ auditors are likely to de-emphasize concerns about decreased reliability as the representation of FASB members from these industries increases. We test these conjectures as

\footnotetext{
${ }^{5}$ Relatedly, the U.S. Second Circuit Court of Appeals has ruled that managers and auditors cannot be held liable for unverifiable fair-value estimates that do not actualize (absent specific evidence of fraud) because there is no objective benchmark against which such estimates can be compared. See Ollman v. Evans, 750 F.2d 970 (DC Cir. 1984). For a fuller discussion of this issue, see Ramanna (2014).
} 
part of our broader examination of the factors likely to shape auditor lobbying on proposed accounting standards.

\section{Data and research design}

\subsection{Measuring decreased reliability in proposed accounting standards}

Big $N$ auditors' assessments of decreased reliability

The FASB's due process provides constituents the opportunity to weigh in on a proposed standard by submitting comment letters. Prior research suggests that comment letters are meaningful indicators of constituent views and have a significant impact on final standards (e.g., Watts and Zimmerman, 1978; Zeff, 2003a, b). We construct our measure of Big N auditors' assessments of decreased reliability using the comment letters written by the auditors on FASB exposure drafts. Our sample begins with the 171 exposure drafts issued by the FASB from 1973 through 2006 that resulted in one or more SFAS: these data are based on Allen and Ramanna (2013, hereafter AR). We find Big $\mathrm{N}$ auditor comment letters on all but 22 of these exposure drafts. In total, we obtain 865 Big $\mathrm{N}$ auditor comment letters covering 149 exposure drafts (and 157 eventual SFAS) in our sample period. See Table 1.

We measure Big $\mathrm{N}$ auditors' reported evaluations of decreased reliability as follows. A paper copy of each Big $\mathrm{N}$ auditor comment letter was obtained from the FASB public library in Norwalk, Connecticut, digitized using optical character recognition and manual transcription, and analyzed using a custom-designed Perl script, which extracted all sentences containing the word stem "reliab." Next, using the output from Perl, a research assistant blind to the intent of our study but trained in accounting principles manually examined the extracted sentences from 
each comment letter to assess the substance of the auditors' reference. Based on this evaluation, comment letters where auditors reported decreased reliability as a result of the exposure draft were identified. See Appendix 2 for further details.

Using the above procedure we find that 98 (10.8\%) of the Big $\mathrm{N}$ auditors' comment letters express the opinion that an exposure draft will decrease accounting reliability. Following AR, our construction of the proxy for the auditors' assessment, called dec_relb_aud, is given by:

$$
d_{e c \_r e l b \_a u d}=1-\frac{W C_{d e c_{r e l b} i j}}{W C_{i j}}
$$

In Equation (1), $W C_{-} d e c_{-} r e l b_{i j}$ is the word count of the first instance of the word stem “reliab” used in the context of decreasing reliability in comment letter $i$ on exposure draft $j$; and $W C_{i j}$ is the total word count of comment letter $i$ on exposure draft $j$. By construction, dec_relb_aud is bounded $[0,1]$ and is intended to capture the relative importance a Big $\mathrm{N}$ auditor places on its assessment of decreased reliability by using relative word position as a proxy for sentiment intensity. As discussed in AR, this linguistic assumption is justified by the propensity of comment letters to begin with an introductory paragraph that highlights key issues. The variable construction should result in higher values of dec_relb_aud for comment letters in which the auditor views reliability as sufficiently important in her overall evaluation of an exposure draft to allude to it earlier in the comment letter. ${ }^{6}$

\footnotetext{
${ }^{6}$ dec_relb_aud is based on the location in comment letters of auditors' concerns about reliability. As a robustness measure, we construct an alternative dependent variable that simply captures the incidence of auditor concerns about decreased reliability (i.e., the variable is independent of location). Our primary results using this alternative dependent variable are qualitatively similar to those we obtain with dec_relb_aud (Table 7). The rest of the paper discusses results using dec_relb_aud because it captures more granular variation in the emphasis auditors place on reliability concerns.
} 


\section{Benchmark assessment of decreased reliability}

To draw inferences on how auditors' comments are influenced by their incentives, we must first condition the Big $\mathrm{N}$ auditors' concerns about decreased reliability on some benchmark measure of the "true" incidence of decreased reliability. To create a benchmark of an exposure draft's "true" impact on reliability that is independent of auditor incentives, we utilize the variable manual_dec_relb from AR, which we rename benchmark for clarity of interpretation in our setting. This variable is constructed from the evaluations of two highly experienced research assistants who were instructed to manually assess each exposure draft's impact on reliability relative to the status quo of GAAP at the time of issuance. The research assistants employed in this task had a combined total experience in the fields of accounting and finance of over 30 years, as well as MBA degrees from top ranked U.S. business schools. The research assistants were blind to the objectives of the study. We use the standard dual-coder model in having the research assistants evaluate the exposure drafts. That is, the research assistants first independently evaluate each exposure draft and then collectively reconciled any differences without interference from us. See Appendix 3 for further details.

By construction, benchmark is a binary indicator for each exposure draft, which takes a value of one for exposure drafts categorized by the research assistants as decreasing accounting reliability. Of the 171 exposure drafts in our population, 145 were available to us from the FASB archives for manual evaluation. Merging this sample of 145 manually evaluated exposure drafts with the 149 exposure drafts for which we have Big $\mathrm{N}$ auditor comment letters yields a common sample of 127 exposure drafts. There are 737 auditor comment letters on these 127 exposure drafts. See Table 1. 


\section{Summary statistics}

Table 2 provides summary statistics for our dependent variable (dec_relb_aud) and benchmark variable (benchmark) across our sample period. As seen in Table 2, the median value of both variables is zero. The benchmark assessment has a mean of 0.28 and the auditors' assessment has a mean of 0.08 , although these values cannot be directly compared in levels. Figures 1 and 2 present the time-series plots of dec_relb_aud and benchmark, respectively, averaged by year across our sample period. For both variables we observe substantial timeseries variation.

\subsection{Regression model and proxies for factors affecting auditor lobbying incentives}

As a starting point, we estimate the correlation between the Big $\mathrm{N}$ auditors’ assessments of decreased reliability and the benchmark incidence of the same, that is, dec_relb_aud and benchmark, respectively. This correlation captures how well the Big $\mathrm{N}$ auditors' assessments map to the "true" assessments. Further, changes in this correlation capture how the auditors' assessments are varying with respect to the truth. We expect the auditors' changing incentives to drive (in part) this variation. Accordingly, in a regression we estimate how changes in the correlation between the auditors' assessments of exposure drafts and the benchmark assessments vary with the three basic factors predicted to shape Big N auditors' incentives. As previously described, these three factors are expected litigation and regulatory costs, client preferences for flexibility, and the auditors' desire to support the FASB's fair-value accounting agenda. Formally, we are interested in the coefficients $\delta_{1} \ldots \delta_{\mathrm{n}}$ from the following regression:

$$
\text { dec_relb_aud } i_{i j}=\left[\begin{array}{c}
\alpha_{1} \\
\alpha_{2} \\
\vdots \\
\alpha_{t}
\end{array}\right]^{\prime} * y r_{-} \text {dummies }+\left[\begin{array}{c}
\beta_{1} \\
\beta_{2} \\
\vdots \\
\beta_{t}
\end{array}\right]^{\prime} * \text { yr_dummies } * \text { benchmark }_{j}
$$




$$
+\left[\begin{array}{c}
\gamma_{1} \\
\gamma_{2} \\
\vdots \\
\gamma_{\mathrm{n}}
\end{array}\right]^{\prime} *\left[\begin{array}{c}
\operatorname{proxy}_{j 1} \\
\operatorname{proxy}_{j 2} \\
\vdots \\
\operatorname{proxy}_{j n}
\end{array}\right]+\left[\begin{array}{c}
\delta_{1} \\
\delta_{2} \\
\vdots \\
\delta_{\mathrm{n}}
\end{array}\right]^{\prime} *\left[\begin{array}{c}
\text { proxy }_{j 1} * \text { benchmark }_{j} \\
\text { proxy }_{j 2} * \text { benchmark }_{j} \\
\vdots \\
\text { proxy }_{j n} * \text { benchmark }_{j}
\end{array}\right]
$$

In the above regression, the subscript $j$ represents a given exposure draft and the subscript $i$ represents a given Big $\mathrm{N}$ auditor comment letter on that exposure draft. The variables $\operatorname{proxy}_{1} \ldots \operatorname{proxy}_{\mathrm{n}}$ represent the set of empirical measures that variously capture each of the three factors predicted to shape Big $\mathrm{N}$ auditors’ lobbying incentives. These proxies are calculated for each exposure draft $j$ in the sample. The coefficients $\delta_{1} \ldots \delta_{\mathrm{n}}$ represent how Big $\mathrm{N}$ auditor lobbying on decreased reliability varies with these proxies, conditional on the "true" incidence of decreased reliability (benchmark).

In the above regression, $y r_{\text {_dummies }}$ is a $t \mathrm{x} 1$ vector of year dummies, which allows variation across the intercept and benchmark slope estimates by year. There are a variety of factors (e.g., macroeconomic and market conditions) that can impact Big $\mathrm{N}$ auditors' mentions of dec_relb_aud in ways that may be unrelated to the true incidence of decreased reliability. These factors are likely to vary by exposure draft and time, and their impact in Equation (2) is captured by the alphas. By interacting $y r \_d u m m i e s$ with the benchmark variable in the above regression, we generate separate beta estimates of the correlation between Big $\mathrm{N}$ auditors' assessments and "true" assessments for each year in our sample. This ensures that the coefficients $\delta_{1} \ldots \delta_{\mathrm{n}}$ do not capture secular variation in the correlation between dec_relb_aud and benchmark that is unrelated to underlying time-series variation in $\operatorname{proxy}_{1} \ldots$ proxy $y_{\mathrm{n}}$. For ease of interpretation we include a full set of year dummies and interactions, and accordingly omit a constant term and the main effect on benchmark. 
Our proxies for the three factors expected to shape Big $\mathrm{N}$ auditors' lobbying incentives are as follows. First, we measure expected litigation and regulatory costs using two separate variables - civil_lit and aaers. The variable civil_lit represents a count of all civil litigation cases filed against Big $\mathrm{N}$ auditors in the twelve months preceding a given exposure draft, scaled by the total number of Compustat firms audited by Big $\mathrm{N}$ auditors in those twelve months. This variable is intended to capture time-series variation in the intensity of civil litigation (and therefore expected litigation costs) against Big $\mathrm{N}$ auditors, controlling for the size of the Big N's client base. The variable aaers represents a count of auditing and accounting enforcement actions filed by the SEC in the twelve months preceding a given exposure draft, scaled by the total number Compustat firms in those twelve months. This variable is intended to capture time-series variation in the intensity of regulatory enforcement (and therefore expected regulatory costs) on accounting and auditing issues.

Our second auditor-incentive factor is client preferences for flexibility. Ideally, we would measure this factor using the sentiments expressed by the auditors' clients in their own comment letters. This would involve manually evaluating tens of thousands of client letters. Given the costs of this approach, we develop three alternative variables to capture client preferences for flexibility. First, we attempt to directly measure the demand for flexibility among the extant client base of Big $\mathrm{N}$ audit firms in the twelve months preceding a given exposure draft. We expect larger clients with more complex operations, clients with more growth options, clients with a longer operating cycle, and clients with more volatile stock returns to demand greater flexibility of the accounting system to better reflect the complexity and changing economics of their businesses. Thus, for each twelve-month period preceding a given exposure draft, we compute a factor using principal component analysis of the following four variables: the median 
total assets (normalized to 1973 dollars) of all firms that are clients of the Big $\mathrm{N}$ auditors; the median Tobin's q of such clients; the median operating cycle of such clients; and the median stock return volatility of such clients. This variable is denoted flexibility.

One drawback with flexibility is that it homogenizes the dispersed nature of clients' preferences for flexibility. To address this limitation, for our second measure of client preferences, we focus on proposed standards that are industry-specific. We define an indicator variable, industry_ED to identify such proposed standards. In cases where industry_ED=1, we expect client interests to be more concentrated. Big $\mathrm{N}$ auditors particularly dependent on an industry might have especially strong incentives to lobby for client preferences on industryspecific standards. Thus, we define a second indicator, aud_specialization, to identify industrydependent auditors lobbying on industry-specific standards. To construct aud_specialization, “industry-dependent auditors" is defined as auditors with an above market weighted-average proportion of clients in each of twelve Fama-French industries. ${ }^{7}$

As a third variable capturing client preferences for flexibility, we measure overall client lobbying intensity on a given exposure draft. The premise here is that if clients feel so strongly on an issue as to directly lobby the FASB, their auditors are more likely to represent the clients' view in their own lobbying. The number of comment letters specifically written by Big $\mathrm{N}$ auditors' clients could proxy for client lobbying intensity, but data limitations prevent us from isolating this number. (It is prohibitively costly to manually determine the number of client

\footnotetext{
${ }^{7}$ Market share is computed by weighting by the natural log of total assets, consistent with prior literature on the determinants of audit fees (e.g., Palmrose, 1986). The results are also robust to using simple averages as in Hogan and Jeter (1999) and to a more restrictive definition of industry dominance that, following Reichelt and Wang (2010), defines an industry specialist as an audit firm having the greatest market share by at least a 10-percentage point margin over the second-largest industry leader.
} 
letters for each exposure draft in our sample.) So we use the total number of comment letters filed on an exposure draft as a proxy for client lobbying intensity. The natural logarithm of this value is denoted num_letters. In general, most of the comment letters on any given exposure draft are written by industrial and financial firms that constitute auditors' clients, which suggests num_letters can be a reasonable proxy for the desired construct.

The third and final factor potentially shaping Big $\mathrm{N}$ auditors' lobbying incentives is their desire to support the FASB in its conceptual agenda on fair-value accounting. This factor is measured using two separate variables, fair_value and pct_fin_fasb. First, we include the indicator variable fair_value that takes the value of one for exposure drafts that increase the use of fair values for asset write downs, asset recognition and measurement, liability recognition and measurement, recognition in the income statement, or any audited disclosure. ${ }^{8}$ Second, we include the variable pct_finfasb, a continuous variable equal to the proportion of FASB members in office at the issuance of a given exposure draft who were employed in the financialservices industry immediately prior to their appointment to the board.

\section{Results}

\subsection{Descriptive statistics}

Table 3 reports summary statistics on the proxies for the three basic factors expected to shape auditor incentives over the sample period, while Figures 3 through 8 depict time trends for these variables. These proxies are described in Section 3.2. As Table 3 reports, on average $0.5 \%$

\footnotetext{
${ }^{8}$ The fair_value variable is based on the variable Manual_inc_relv in AR, which is constructed by two seasoned research assistants who evaluate exposure drafts for their use of fair values along the five dimensions described above. Further details on this variable are provided in Appendix B of AR.
} 
and $0.6 \%$ of all Compustat firms are subject to civil litigation (civil_lit) or SEC enforcement action (aaers), respectively, each year. Turning to variables capturing clients' preferences for flexibility, industry-specific exposure drafts constitute $23 \%$ of our sample (industry_ED); also, 8.5\% of corresponding comment letters are written by Big $\mathrm{N}$ auditors having market-share dominance in the industry to which the exposure draft pertains (aud_specialization). On average, 176 comment letters are received in response to a FASB exposure draft (num_letters), however participation ranges from a low of 4 letters (SFAS 152: Accounting for Real Estate Time Sharing Transactions) to a high of 6,536 letters (SFAS 123R: Share Based Payments). ${ }^{9}$ Also from Table 3 , we note that on average $24 \%$ of exposure drafts in our sample increase the use of fair values in accounting (fair_value).

As Figures 3 and 4 show, the proportion of firms subject to civil litigation and SEC enforcement action, respectively, are increasing over our sample period, but with significant time-series variation. Specifically, civil litigation appears to increase and decrease in a pattern generally consistent with the changes in auditor-litigation eras discussed in Section 4.3. Figure 5 suggests that flexibility, our proxy for median client demand for flexibility, has steadily risen over time. By contrast, Figure 6 suggests there is no apparent time-trend to the intensity of comment-letter lobbying, our proxy for client engagement in the standard setting process (num_letters). Finally, Figures 7 and 8 depict the increasing time trend in fair value use and in the proportion of FASB members, previously documented in AR.

\footnotetext{
${ }^{9}$ Note, for ease of interpretation the value of num_letters presented in Table 3 is prior to the log transformation.
} 


\subsection{Multivariate results}

Table 4 presents the results of our multivariate tests to determine how auditor lobbying incentives vary with changes in civil litigation and SEC enforcement action. The regression follows the form of Equation (2) in Section 3.2. Columns (1) and (2) of Table 4 test civil litigation and SEC enforcement separately, in Column (3) proxies for both effects are included. The regression structure includes both year fixed-effects and year fixed-effects interacted with our benchmark variable to control for omitted factors unrelated to litigation or regulatory costs. Statistical significance is reported based on heteroskedastic cluster-robust standard errors.

Table 4 suggests that auditors are significantly more likely to express concerns with decreased reliability in proposed accounting standards (conditional on an exposure draft's "true" impact) when the perceived threat of civil litigation and regulatory action is higher. The variables civil_lit*benchmark and aaers*benchmark are significantly positive at a 5\% level across all specifications in the table. Based on the coefficients from Column (3), a one standard-deviation increase in the proportion of firms targeted in civil litigation (SEC auditing and enforcement actions) over the twelve months preceding an exposure draft is associated with an increase in 1.61 (1.86) standard deviations of the value of dec_relb_aud.

Table 5 presents the results of multivariate analysis on how auditor lobbying incentives vary with changes in client preferences for flexibility. The regression structure and presentation underlying Table 5 mirrors that of Table 4 . We find a significantly negative coefficient on the variable flexibility, suggesting that the raw incidence of Big $\mathrm{N}$ auditors' expressing concerns about decreased reliability is lower when client demand for flexibility is higher. But the coefficient of interest - that on the interaction of flexibility with benchmark, which captures the conditional propensity of Big $\mathrm{N}$ auditors' to express concerns about decreased reliability - is not 
statistically significant in Table 5. Further, we fail to find evidence that industry-specific standards and auditor specialization has a significant impact on auditors' concern with reliability. Put differently, our attempt at isolating a high-power setting to test for the impact of client preferences for flexibility on auditor lobbying does not yield significant inferences.

The only variable for client preferences that appears to significantly impact auditor incentives is num_letters, our proxy for the relative importance of an accounting issue to clients. But the effect is in the opposite direction as predicted. Regression coefficients (significant at the 5\% level) suggest that auditors are more likely to highlight concerns with decreased reliability (conditional on its true incidence) when accounting proposals generate significant volumes of comment letters. Assuming that lobbying activity is proportional to projected financial statement impact, this result potentially suggests that auditors are more wary of standards that decrease reliability when the projected financial statement impact of such standards is deemed more material. In other words, auditors appear to be concerned about litigation and regulatory costs when the volume of total lobbying activity on a given accounting proposal is higher.

Overall, Table 5 provides no support for the argument that auditor lobbying over time is driven by changing client preferences for flexibility. This finding is consistent with prior studies of auditor lobbying (e.g., Watts and Zimmerman, 1982; Puro, 1984).

Table 6 presents the results of multivariate analysis on how auditor lobbying varies with the incidence of fair-value accounting proposals. The regression structure and presentation of Table 6 is as in Tables 4 and 5. The coefficient on fair_value is positive and statistically significant (at the $1 \%$ level), suggesting that the raw incidence of Big $\mathrm{N}$ auditors' expressing concerns about decreased reliability is higher on exposure drafts advancing fair-value 
accounting. However, the coefficient on the interaction of fair_value and benchmark, which captures the conditional propensity of Big $\mathrm{N}$ auditors' to express concerns about decreased reliability, is negative and statistically significant (at the $5 \%$ level). This result suggests that Big $\mathrm{N}$ audit firms are less likely to voice concerns about decreased reliability (conditional on the true incidence of such) when an exposure draft increases the use of fair value accounting methods. This finding is consistent with the anecdotal evidence of the Big $\mathrm{N}$ auditors' support for fairvalue accounting discussed in Section 3.2.

In Table 6, we also find that the coefficient on pct_fin_fasb when interacted with benchmark is negative and statistically significant. This result suggests that that Big $\mathrm{N}$ audit firms are less likely to voice concerns about decreased reliability (conditional on the true incidence of such) as the proportion of FASB members with backgrounds in financial services increases. This result is also consistent with the Big $\mathrm{N}$ being supportive of the move toward more fair values in GAAP. Overall Table 6 provides evidence consistent with Big $\mathrm{N}$ auditors supporting the FASB in its conceptual agenda on fair-value accounting. Note that this interpretation does not preclude auditor support for fair-value accounting being also driven by their desire to support those clients who seek to advance fair-value accounting (e.g., investment bankers and asset managers).

Finally, in Table 7 we present results with the full multivariate model that estimates variation in auditor lobbying with the seven variables spanning expected litigation and regulatory costs, client preferences for flexibility, and desire to support the FASB's fair-value agenda. The regression results confirm that the Big $\mathrm{N}$ are more likely to emphasize concerns regarding decreased reliability in proposed standards when the risk of either civil litigation or regulatory intervention is more severe. On the other hand, the Big $\mathrm{N}$ tend to de-emphasize their concerns 
regarding decreased reliability when proposed standards more extensively incorporate fair-value estimations and when the FASB is more dominated by finance professionals (who tend to exhibit a preference for fair-value standards). The results provide no support for the hypothesis that clients’ preferences for reporting flexibility influence auditor lobbying.

Overall, the evidence from Tables 4 to 7 suggests that auditors' concerns regarding litigation and regulation, together with their desire to support the FASB in its conceptual agenda on fair-value accounting, bear a greater influence on their comment-letter lobbying than the preferences of their clients for flexibility. One caveat to this inference applies: despite our best attempts to generate proxies that (indirectly) capture clients' preferences for flexibility, data limitations preclude us from generating a more direct measure based on clients’ comment letters on proposed standards. Absent these data, it would be premature to rule out the possibility that evolving client preferences for flexibility have shaped auditors' lobbying incentives over time.

\subsection{Additional tests of the changing nature of Big $N$ auditor lobbying}

As an alternative approach to examining the changing nature of Big $\mathrm{N}$ auditor lobbying, we investigate the time-series variation in the correlation between $d e c \_r e l b \_a u d$ and benchmark across broad regime shifts that potentially alter the relative weight that auditors place on their various incentives. We look at two sets of regime shifts in particular - the changing nature of auditor liability to capital-market participants, as determined by evolving legislation and judicial precedent, and the changing industrial organization of the auditing oligopoly, specifically the gradual decline in the number of Big $\mathrm{N}$ auditors from eight to four. In each of these regime shift tests, we estimate the following regression in order to extract the coefficients $\beta_{1} \ldots \beta_{\mathrm{t}}$. 


$$
\text { dec_relb_aud } d_{i j}=\left[\begin{array}{c}
\alpha_{1} \\
\alpha_{2} \\
\vdots \\
\alpha_{t}
\end{array}\right]^{\prime} * y r_{-} \text {dummies }+\left[\begin{array}{c}
\beta_{1} \\
\beta_{2} \\
\vdots \\
\beta_{t}
\end{array}\right]^{\prime} * y r_{-} \text {dummies } * \text { benchmark }_{j}
$$

Then, we compare the average betas across different regime "eras" of auditor liability and auditor industrial organization (the specifics of these eras are discussed shortly). To do so, we use linear combinations of betas within a given era to calculate the era-average coefficients and standard errors per the following equations.

$$
\begin{gathered}
\text { Era-Average Coefficient }=\boldsymbol{l}^{\prime} \boldsymbol{\beta}=\sum_{\boldsymbol{k}=\mathbf{1}}^{\boldsymbol{K}} \boldsymbol{l}_{\boldsymbol{k}} \boldsymbol{\beta}_{\boldsymbol{k}} \\
\operatorname{se}\left(l^{\prime} \beta\right)=\left[\hat{\sigma}^{2} l^{\prime}\left(x^{\prime} x\right)^{-1} l\right]^{\frac{1}{2}}
\end{gathered}
$$

In Equations (4) and (5), $l$ is an $t \times 1$ matrix (where $t$ is the sample length) that has element $k$ set to one for each $\beta_{k}$ being averaged across a given era and zero otherwise. In Equation (5), $\hat{\sigma}^{2}$ is the regression's sum of squared residuals divided by the degrees of freedom and $x$ is the matrix of explanatory variables. Significance tests of era-averaged coefficients are based on a Student's $t$-distribution with $n-K$ degrees of freedom, where $n$ is the sample size and $K$ is the number of regression covariates.

Note that if the Big $\mathrm{N}$ auditors' incentives are unchanged across eras or if the auditors are, on average, not self-serving in their lobbying, we are unlikely to find significant differences across era-averaged beta coefficients. If, on the other hand, Big $\mathrm{N}$ auditors' lobbying on exposure drafts is influenced by changing incentives across liability regimes or regimes of industrial organization, differences across era-averaged coefficients will be significant. 


\section{Auditor liability eras}

Consider, first, the regime shifts across changing auditor liability. Following the evolution of tort law related to auditor liability in our sample period, we identify four distinct litigation eras over our 1973 to 2006 sample period.

(1) 1973-1982 constitutes our baseline period. During this period tort law governing auditor liability to non-clients for negligence was largely governed by the doctrine of "privity" (Feinman, 2003). Under the doctrine of privity, auditors can only be held liable for negligence to third parties with whom they have a direct contractual relationship. ${ }^{10}$

(2) 1983-1991 was a period marked by increase in litigation pressure felt by the large auditing firms. Two major court rulings in 1983, Rosenblum v. Adler and Citizens State Bank v. Timm Schmidt and Co., set precedents for the use of "reasonable foreseeability" rather than "privity" as the standard for negligence (Kothari et al., 1988). Under the doctrine of "reasonable foreseeability,” auditor litigation risk is significantly increased; an auditor is potentially liable to any party that might have been reasonably expected to rely on a client's audited financial statements. Also in 1983, the U.S. courts held that auditors could be sued under the Racketeer Influenced and Corrupt Organization Act (RICO) of 1970 (Lys and Watts, 1994).

(3) 1992-2002 was a period that saw a series of reforms aimed at decreasing auditor liability. In 1992, two court cases Bily v. Arthur Young and Co. and Security Pacific Business Credit v. Peat Marwick Main, reversed the precedent set in Rosenblum. Rejecting the doctrine of

\footnotetext{
${ }^{10}$ Kothari et al. (1988) in their discussion of auditor liability eras identify the Ernst \& Ernst v. Hochfelder case in 1976 as demarking a reduction in auditor liability. Applied to our setting, this would suggest that we treat the periods 1973-1976 and 1977-1982 differently. We do not do so because we lack sufficient observations (based on limited data to construct the benchmark variable) to generate regression betas for the 1973-1976 period.
} 
"reasonable foreseeability", both court cases instead applied the doctrine of "known users" (Feinman, 2003). By this standard auditor liability for negligent misrepresentation to non-clients is limited to third parties whom the auditor knows rely on its audit reports. Also, in 1992 the AICPA amended Section 505 of its Code of Professional Conduct to allow member firms to incorporate as limited liability partnerships; and, the Big N firms all converted shortly thereafter (Choi, Doogar, and Ganguly, 2004). In 1994, the Supreme Court eliminated auditors’ liability for aiding and abetting rule 10b-5 violations (Central Bank of Denver v. First Interstate Bank of Denver). And finally, in 1995 the Private Securities Litigation Reform Act of 1995 further reduced auditor liability by limiting key aspects of their liability under the 1934 Securities Act and under RICO (Ali and Kallapur, 2001). The sum effect of these changes was a reduction in litigation risk for auditors relative to the prior period.

(4) 2003-2006 was a period marked by increased litigation risk relative to the prior period. The provisions of the Sarbanes Oxley Act of 2002 (SOX) left largely untouched the private civil liability standards for auditors, but established the Public Company Accounting Oversight Board for increased oversight and visibility of Big $\mathrm{N}$ audit firms. Further, the high visibility of corporate accounting scandals from 2001-2002, the demise of Arthur Andersen, and the ensuing wave of investigations and penalties for public accounting firms likely heightened Big N audit firms incentives to minimize litigation risk (Cahan and Zhang, 2006).

Consistent with our earlier predictions on auditor litigation risk, we expect eras with heightened (diminished) litigation risk to increase (decrease) Big $\mathrm{N}$ auditors' likelihood of expressing concerns about decreased reliability. The specific predictions are summarized below:

\begin{tabular}{lll}
\hline Era & $\begin{array}{l}\text { Legal liability standard (change } \\
\text { relative to preceding era) }\end{array}$ & $\begin{array}{l}\text { Beta predictions relative } \\
\text { to preceding era }\end{array}$ \\
\hline
\end{tabular}




\begin{tabular}{lll}
\hline 1973-1982 & Privity (baseline) & Baseline \\
1983-1991 & $\begin{array}{l}\text { Reasonable Foreseeability (increase) } \\
\text { Known Users and Limited Liability }\end{array}$ & Increased Beta \\
1992-2002 & $\begin{array}{l}\text { Decreased Beta } \\
\text { (decrease) }\end{array}$ SOX and PCAOB (increase) & Increased Beta \\
\hline
\end{tabular}

Table 8 presents the results of this analysis. The underlying regression for Table 8 is given by Equation (3). The coefficients and their standard errors are calculated as in Equations (4) and (5). The first column of Table 8 reports the average beta (i.e., correlation between dec_relb_aud and benchmark) for each of the four auditor litigation eras. Differences in average coefficients for each pair of eras are presented in the second through fourth columns of Table 8.

As shown in Table 8, litigation era coefficients increase (decrease) systematically as predicted in response to heightened (diminished) legal accountability of auditors. Big $\mathrm{N}$ auditor concern with decreased reliability (conditional on the true incidence of such) is lowest under the legal standard of privity, increases under the more relaxed doctrine of "reasonable foreseeability" (0.31), decreases under the more stringent standard of "known users" (0.19), and increases again post-SOX (0.36). All predicted pairwise differences across each of these era coefficients (diagonal elements) are statistically significant at the 5\% level. Overall, Table 8 provides additional evidence that the Big $\mathrm{N}$ auditors’ lobbying systematically shifts toward managing their litigation and regulatory costs in "unfriendly” litigation eras.

\section{Auditor industrial-organization eras}

Next, we consider the eras representing regimes of the Big N's industrial organization over our sample period. The audit business in the US has since at least the 1970s functioned as a 
relatively tight oligopoly, with a few big firms providing a disproportionately large share of audit services. The dominance of the audit firms has been particularly pronounced among larger clients. In 1988, only eight firms collectively audited approximately $98 \%$ of all public companies by sales ( $82 \%$ by number). Thereafter, the concentration of audit firms increased progressively to the point that in 2002 there were only four firms auditing almost 99\% of all public companies by sales (78\% by number). ${ }^{11}$ The specific consolidations that led to the emergence of the Big 4 from the Big 8 are outlined in Appendix 1. Briefly, the consolidations characterize four distinct oligopoly eras in our sample period from 1973 through 2006: the Big 8 era (1973-1989), the Big 6 era (1990-1998), the Big 5 era (1999-2002) and the Big 4 era (2003-2006).

The primary factor driving the increasing concentration of Big $\mathrm{N}$ audit firms has been mergers between existing firms. The mergers, in turn, appear to have been motivated by Big $\mathrm{N}$ audit firms' attempts to achieve economies of scale in servicing a client base that increasingly spans diverse operational and geographic boundaries (e.g., DeAngelo, 1981; Benston, 1985). Changing litigiousness over time may have also contributed toward auditors' proclivity to merge. Bigger firms with a wider pool of resources are presumably in a better position to withstand the threats, and costs, arising from class-action lawsuits (GAO, 2008). Higher concentration does not, however, guarantee the ability to survive litigation and political threats, as the case of Arthur Andersen demonstrates. In 2002, the criminal indictment of Arthur Andersen for its culpability as auditor in the accounting fraud perpetuated by Enron Corporation led to unprecedented client flight, as well as voluntary departures of several of its partners and staff, ultimately resulting in its dissolution.

\footnotetext{
${ }^{11}$ See GAO (2003), a study conducted by Government Accountability Office for the Senate Committee on Banking, Housing, and Urban Affairs and the House Committee on Financial Services.
} 
The Big N's lobbying incentives are expected to evolve with a tightening oligopoly due to a number of factors. Fewer Big $\mathrm{N}$ firms available to undertake audits of large and complex clients implies that the potential systemic instability and cost to the financial system that could result from the failure of a single oligopolistic audit firm rises. This can make regulators reluctant to aggressively pursue auditors in the event of irregularities, effectively rendering them "too big to fail."12 Less fettered by the need to manage the risk of regulatory intervention, a tighter Big $\mathrm{N}$ oligopoly can be expected to care less about decreased reliability in accounting standards, shifting instead toward emphasizing client preferences for accounting flexibility.

However, countervailing forces exist. A decline in the number of Big $\mathrm{N}$ firms without a decline in their collective market share has translated into the remaining firms becoming more visible, making them more noticeable targets for litigation. The perception of deep pockets heightens motives among capital market participants, including investors, to launch class-action lawsuits against Big N auditors alleging dereliction of fiduciary duties (e.g., Calabresi, 1970; Palmrose, 1988). Increased visibility to regulators is also a potential issue, as it can conceivably increase regulators' incentives to scrutinize big audit firms more carefully. If a tightening oligopoly indeed increases auditors' visibility and as a consequence, their litigation and regulatory costs, the Big $\mathrm{N}$ are increasingly more likely to emphasize concerns about the decreased reliability of proposed standards when such concerns are present. Compounding the effect of higher visibility is the improved bargaining power vis-à-vis clients the Big $\mathrm{N}$ enjoy when their numbers decline. As Big $\mathrm{N}$ audit firms have fewer competitors, the market-driven

\footnotetext{
${ }^{12}$ For example, in 2005, when the Big 4 audit firm KPMG was revealed to be "peddling illegal tax shelters" among its clients (Nocera, 2005), the U.S. Justice Department signed a deferred prosecution agreement with the firm, forcing it to admit wrongdoing but sparing it from criminal prosecution. For additional arguments on the Big $\mathrm{N}$ being “too big to fail," see, e.g., Dwyer (2003), Cunningham (2006), and Salmon (2011).
} 
need to be responsive to clients' preferences is weaker, and auditors can focus on managing their exposures to litigation and regulatory risk. This can further shift the Big N's preferences toward emphasizing concerns about decreased reliability in their comment letters.

In tests presented in Table 9, we examine these competing predictions on Big $\mathrm{N}$ auditors' lobbying over decreased reliability across the changing nature of the auditors' industrial organization. The regression structure and presentation for Table 9 mirror those of Table 8 , except that betas (the correlation between dec_relb_aud and benchmark) are average across oligopoly eras as opposed to litigation regimes. The first column of Table 9 suggests that Big $\mathrm{N}$ auditor concern with decreased reliability (conditional on the true incidence of such) is increasing monotonically with increased concentration of the audit oligopoly. The second through fourth columns of Table 9 provide pairwise differences between era-averaged betas, which are all positive and statistically significant (at the $10 \%$ level) with the exception of the Big 8 to Big 6 era comparison.

The results in Table 9 suggest that as the auditing oligopoly has tightened, Big $\mathrm{N}$ auditors are more likely to emphasize concerns about decreased reliability in their comment letters. This finding is consistent with the surviving Big $\mathrm{N}$ audit firms in the tightening oligopoly facing greater political and litigation costs attributable to their increased visibility. The finding is also consistent with decreased competitive pressure among the Big $\mathrm{N}$ to satisfy client preferences as the oligopoly tightens. These forces appear to dominate any increased perception by the Big $\mathrm{N}$ that they are "too big to fail" as the audit oligopoly tightens. 


\section{Conclusion}

Our paper offers a descriptive analysis of the role of auditors in accounting standardsetting, a subject on which there has been no systematic empirical study for nearly thirty years. We focus, in particular, on how auditors' changing incentives impact their comment-letter lobbying on proposed financial reporting standards over the period from 1973 through 2006 . We characterize auditors' incentives arising from three distinct sources: their desire to manage their expected litigation and regulatory costs, their desire to cater to their clients' preferences for flexibility, and their desire to support the FASB in its conceptual agenda on fair-value accounting. Our empirical analysis focuses on the influential Big $\mathrm{N}$ auditors and a crucial property of standards that auditors commonly comment on, reliability. We are careful to control for the component of auditor lobbying driven solely by the properties of the proposed standards themselves, via the use of a benchmark designed to capture "true” concerns regarding reliability that would be raised by a neutral assessment.

Our findings indicate support for expected litigation costs as well as the threat of regulatory scrutiny being important factors guiding auditor lobbying. In the presence of those forces, the Big $\mathrm{N}$ are more prone to emphasize their concerns regarding the decreased reliability of proposed standards, relative to the benchmark. Despite several attempts to increase the power of our tests, we fail to find evidence that auditor lobbying caters to their clients' preferences for flexibility, which would be hindered by reporting standards that stress reliability. Finally, the results suggest that auditor lobbying reflects their desire to support the FASB in its conceptual agenda on fair-value accounting. The Big $\mathrm{N}$ tend to de-emphasize the reliability concerns of proposed standards when those standards advocate greater use of fair values and when they are proposed by a FASB board more dominated by finance professionals. Watts and Zimmerman 
(1986) note that auditors have incentives to support the FASB on accounting matters so as to be able to continue to effect wealth transfers through accounting regulation.

In regime-shift analyses, results confirm that Big $\mathrm{N}$ auditor lobbying focuses more on concerns regarding the reliability of proposed standards during litigation regimes that lower the bar for assessing auditor liability. Interestingly, we also find that the Big $\mathrm{N}$ have increasingly emphasized concerns regarding reliability as their oligopoly has tightened over time, i.e., as their numbers have progressively dwindled from eight to four. The findings are consistent with Big $\mathrm{N}$ auditors perceiving higher litigation and political costs from the increased visibility that accompanies a tighter oligopoly. The findings are also consistent with tighter oligopoly decreasing competition among the surviving Big $\mathrm{N}$ to satisfy client preferences in accounting standards (preferences for accounting flexibility at the expense of verifiability). The findings are not consistent with the concern that tightening oligopoly has rendered the surviving Big $\mathrm{N}$ "too big to fail.”

Opportunities for future research abound in the general arena of auditors' role in standard-setting and the political process underlying the development of financial reporting standards. For example, we refrain from assessing an exhaustive list of properties of financial reporting standards (e.g., comparability, consistency), primarily because they are either not referenced as frequently in comment letters or because it is difficult to predict variation in the extent to which auditors emphasize their concerns regarding these properties as their incentives evolve. Nevertheless, it would be valuable to track how different parties including auditors advocate key attributes of reporting standards such as reliability, relevance, comparability and consistency in line with their own incentives. Our goal is to provide a stepping stone for this 
research by offering the first large-sample descriptive study on how Big $\mathrm{N}$ auditors' incentives shape their attempts to influence U.S. GAAP. 


\section{References:}

Ali, A., and S. Kallapur. 2001. Securities price consequences of the Private Securities Litigation Reform Act of 1995 and related events. The Accounting Review 76: 431-460.

Allen, A., 2013. Agenda setting at the FASB: Evidence from the role of the FASAC. Working Paper, Harvard Business School.

Allen, A., and K. Ramanna. 2013. Toward an understanding of the role of standard setters in standard setting. Journal of Accounting \& Economics 55: 66-90.

Benston, G. 1985. The market for public accounting services: Demand, supply and regulation. Journal of Accounting \& Public Policy 4: 33-79.

Brochet, F., K. Palepu, and L. Barley. 2011. Accounting for the iPhone at Apple Inc. Harvard Business School Case No. 111-003.

Cahan, S., and W. Zhang. 2006. After Enron: Auditor conservatism and ex-Andersen clients. The Accounting Review 81: 49-82.

Calabresi, G. 1970. The Cost of Accidents: A Legal and Economic Analysis. New Haven, CT: Yale University Press.

Chakravarthy, J. 2014. The Ideological Homogenization of the FASB. Working Paper, Emory University.

Choi, J., R. Doogar, and A. Ganguly. 2004. The Riskiness of Large Audit Firm Client Portfolios and Changes in Audit Liability Regimes: Evidence from the U.S. Audit Market. Contemporary Accounting Research 21: 747-785.

Cunningham, L. 2006. Too Big to Fail: Moral Hazard in Auditing and the Need to Restructure the Industry before It Unravels. Columbia Law Review 106: 1698-1748.

DeAngelo, L. 1981. Auditor size and audit quality. Journal of Accounting \& Economics 3: 183199.

Deakin, E. 1989. Rational Economic Behavior and Lobbying on Accounting Issues: Evidence from the Oil and Gas Industry. The Accounting Review 64: 137-151.

Dechow, P., A. Hutton, and R. Sloan. 1996. Economic Consequences of Accounting for StockBased Compensation. Journal of Accounting Research 34: 1-20.

Dechow, P., R. Sloan, and A. Sweeney. 1996. Causes and consequences of earnings manipulation: An analysis of firms subject to enforcement actions by the SEC. Contemporary Accounting Research 13: 1-36.

DeFond, M. and J. Zhang. 2014. A review of archival auditing research. Journal of Accounting \& Economics 58: 275-326. 
Donelson, D., J. McInnis, and R. Mergenthaler. 2012. Rules-Based Accounting Standards and Litigation. The Accounting Review 87: 1247-1279.

Dwyer, P. 2003. The Big Four: Too few to fail. BusinessWeek, August 31.

Farber, D., M. Johnson, and K. Petroni. 2007. Congressional intervention in the standard-setting process: An analysis of the Stock Option Accounting Reform Act of 2004. Accounting Horizons 21: 1-22.

Feinman, J. 2003. Liability of Accountants for Negligent Auditing: Doctrine, Policy, and Ideology. Florida State Law Review 31: 17-65.

Feroz, E., K. Park, and V. Pastena. 1991. The financial and market effects of the SEC's accounting and auditing enforcement releases. Journal of Accounting Research 29: 107142.

Files, R. 2012. SEC enforcement: Does forthright disclosure and cooperation really matter? Journal of Accounting \& Economics 53: 353-374.

Financial Accounting Standards Board (FASB). 1980. Statement of Financial Accounting Concepts No. 2, Qualitative Characteristics of Accounting Information. Norwalk, CT: FASB.

Folsom, D., P. Hribar, R. Mergenthaler, and K. Peterson. 2013. Principles-based standards and earnings attributes. Working Paper, University of Iowa.

Francis, J. 1987. Lobbying Against Proposed Accounting Standards: The Case of Employer's Pension Accounting. Journal of Accounting \& Public Policy 6: 35-57.

Geiger, M., and K. Raghunandan. 2001. Bankruptcies, audit reports, and the reform act. Auditing: A Journal of Practice and Theory 20: 187-195.

Gipper, B., B. Lombardi, and D. Skinner. 2013. The Politics of Accounting Standard-Setting: A Review of Empirical Research. Australian Journal of Management 38: 523-551.

Government Accountability Office (GAO). 2003. Public Accounting Firms: Mandated Study on Consolidation and Competition. Washington, DC: GAO.

Government Accountability Office (GAO). 2008. Audits of Public Companies: Continued Concentration in Audit Market for Large Public Companies Does Not Call for Immediate Action. Washington, DC: GAO.

Hogan, C., and D. Jeter. 1999. Industry specialization by auditors. Auditing: A Journal of Practice and Theory 18: 1-17.

Jiang, J., I. Wang, and Y. Xie. 2014. Does it Matter Who Serves on the Financial Accounting Standards Board? Bob Herz's Resignation and Fair Value Accounting for Loans. Review of Accounting Studies, forthcoming. 
Kalt, J., and M. Zupan. 1984. Capture and ideology in the economic theory of politics. The American Economic Review 74: 279-300.

Karpoff, J., D. Lee, and G. Martin. 2008. The consequences to managers for financial misrepresentation. Journal of Financial Economics 88: 193-215.

Kinney, W. 1986. Audit technology and preferences for auditing standards. Journal of Accounting \& Economics 8: 73-89.

Kothari, S., T. Lys, C. Smith, and R. Watts. 1988. Auditor Liability and Information Disclosure. Journal of Accounting, Auditing \& Finance 3: 307-339.

Kothari, S., K. Ramanna, and D. Skinner. 2010. Implications for GAAP from an analysis of positive research in accounting. Journal of Accounting \& Economics 50: 246-286.

Lee, H. and V. Mande. 2003. The effect of the private securities litigation reform act of 1995 on accounting discretion of client managers of Big 6 and non-Big 6 auditors. Auditing: A Journal of Practice and Theory 22: 93-108.

Leftwich, R. 1995. The agenda of the financial accounting standards board. Working Paper, University of Chicago.

Lys, T., and R. Watts. 1994. Lawsuits against Auditors. Journal of Accounting Research 32, 6593.

Mian, S, and C. Smith. 1990. Incentives associated with changes in consolidated reporting requirement. Journal of Accounting \& Economics 13: 249-266.

Nocera, J. 2005. Auditors: Too few to fail. The New York Times, June 25.

Palmrose, Z. 1986. Audit fees and auditor size: further evidence. Journal of Accounting Research 24: 97-110.

Palmrose, Z. 1988. An analysis of auditor litigation and audit service quality. The Accounting Review 63: 55-73.

Puro, M. 1984. Audit firm lobbying before the Financial Accounting Standards Board: An empirical study. Journal of Accounting Research 22: 624-646.

Ramanna, K. 2008. The implications of unverifiable fair-value accounting: evidence from the political economy of goodwill accounting. Journal of Accounting \& Economics 45: 253281.

Ramanna, K. 2014. Political Standards: Accounting for Legitimacy. Chicago, IL: The University of Chicago Press, forthcoming.

Ramanna, K., and R. Watts. 2012. Evidence on the use of unverifiable estimates in required goodwill impairment. Review of Accounting Studies 17: 749-780. 
Reichelt, K., and D. Wang. 2010. National and Office-Specific Measures of Auditor Industry Expertise and Effects on Audit Quality. Journal of Accounting Research 48: 647-686.

Salmon, F. 2011. The impunity of the Big Four auditors. Reuters, October 28.

Snyder, J. 1992. Long-term investing in politicians; or, give early, give often. Journal of Law and Economics 35: 15-43.

St. Pierre, K., and J. Anderson. 1984. An Analysis of the Factors Associated with Lawsuits against Public Accountants. The Accounting Review 59: 242-263.

Stickney, C., R. Weil, K. Schipper, and J. Francis. 2010. Financial Accounting (13e). Mason, OH: South-Western Cengage Learning.

Watts, R. 2003. Conservatism in accounting Part I: explanations and implications. Accounting Horizons 17: 207-221.

Watts, R., and J. Zimmerman. 1978. Towards a positive theory of the determination of accounting standards. The Accounting Review 53: 112-134.

Watts, R., and J. Zimmerman. 1982. Auditors and the Determination of Accounting Standards. Working Paper, University of Rochester.

Watts, R., and J. Zimmerman. 1986. Positive Accounting Theory. Cliffs, NJ: Prentice-Hall.

Zeff, S. 2003a. How the US accounting profession got where it is today: Part I. Accounting Horizons 17: 189-205.

Zeff, S. 2003b. How the US accounting profession got where it is today: Part II. Accounting Horizons 17: 267-286. 


\section{Appendix 1: \\ Tightening of the Big N auditing oligopoly, 1973-2006}

\begin{tabular}{|c|c|c|c|}
\hline Big 8 & Big 6 & Big 5 & Big 4 \\
\hline 1973-1989 & 1990-1998 & 1999-2002 & 2003-2006 \\
\hline Arthur Andersen & Arthur Andersen & Arthur Andersen & \\
\hline $\begin{array}{l}\text { Arthur Young } \\
\text { Ernst \& Whinney }\end{array}$ & Ernst \& Young & Ernst \& Young & Ernst \& Young \\
\hline $\begin{array}{l}\text { Touche Ross } \\
\text { Deloitte, Haskins } \\
\text { \& Sells }\end{array}$ & Deloitte Touche & Deloitte Touche & Deloitte Touche \\
\hline Peat Marwick & KPMG & KPMG & KPMG \\
\hline $\begin{array}{l}\text { Coopers Lybrand } \\
\text { Price Waterhouse }\end{array}$ & $\begin{array}{l}\text { Coopers Lybrand } \\
\text { Price Waterhouse }\end{array}$ & PwC & PwC \\
\hline
\end{tabular}

Arthur Young and Ernst \& Whinney merged in July of 1989. Deloitte, Haskin \& Sells and Touche Ross merged in August of 1989. Coopers Lybrand and Price Waterhouse merged in July 1998. Arthur Andersen surrendered its CPA licenses and right to practice in August of 2002. 


\section{Appendix 2: \\ Details of the process for creating auditor-based measures of decreased reliability}

We use a custom-designed Perl script to analyze the Big N auditors' comments letters. For each comment letter, the Perl program first identifies all instances of the word stem "reliab." The program then outputs: (1) the exact position within the comment letter where the word stem occurs (the position of a word stem is reported as its word count from the beginning of the document); (2) the entire sentence containing the identified word stem; and (3) the total word count for the letter.

Next, a research assistant (RA) trained in accounting principles, but blind to the intent of our study, manually examines the first sentence referencing "reliab." On each sentence, the RA determines whether the word stem in question is being used in: (1) a positive context, i.e., whether the letter is indicating that the proposed standard will increase reliability; (2) a negative context, i.e., whether the letter is indicating that the proposed standard will decrease reliability; or (3) a context that is irrelevant to the use of reliability as an accounting principle. What follows is an example of the RA's assessment from an actual sentence capturing decreased reliability. "We also believe the Proposed Standard exacerbates the complexities of Statement 125 and permits recognition of revenue that cannot be reliably measured." Source: Deloitte's comment letter on proposed SFAS 140.

In instances where the RA identifies the comment letter's first use of reliability as irrelevant to accounting principles, the RA proceeds to the second sentence containing the word stem in question. This process continues until the RA encounters either a positive or negative use of reliability or the RA determines that all uses of reliability in the comment letter are irrelevant to accounting principles.

Note: this appendix is adapted from Appendix A of Allen and Ramanna (2013). 


\section{Appendix 3: \\ Coding rubric for research-assistant-based measures of decreased reliability}

The research assistants were instructed to evaluate the exposure drafts recording their perspective on whether the underlying proposal would decrease reliability, where "reliability" is defined as per the FASB as, "The quality of information that assures that information is reasonably free from error and bias and faithfully represents what it purports to represent." The resulting variable is a binary indicator denoted benchmark.

Assessing benchmark requires the exercise of professional judgment. Accordingly, both research assistants employed for this task are seasoned professionals, with MBA degrees from top-ranked U.S. business schools (as per U.S. News rankings) and with combined industrial work experience in finance and accounting exceeding thirty years. We recruited both research assistants specifically to evaluate the FASB exposure drafts, and both were selected for their practical familiarity with accounting.

Of the 145 exposure drafts coded by the two research assistants, 105 received identical independent evaluations on benchmark. On the exposure drafts with differing evaluations, the research assistants were able to resolve all differences in subsequent discussions. (This is the standard dual-coder model.) At no point in this process were the research assistants apprised of the study's hypotheses or its independent variables. Research assistants were compensated on a flat hourly wage (i.e., no performance-based pay).

Note: this appendix is adapted from Appendix B of Allen and Ramanna (2013). 


\section{Figure 1:}

Big $\mathbf{N}$ auditor assessments of decreased reliability in proposed standards

The sample is based on 737 Big $\mathrm{N}$ auditor comment letters on 127 distinct exposure drafts issued between 1973 and 2006. dec_relb_aud is the auditors' assessment that a proposed standard will decrease accounting reliability.

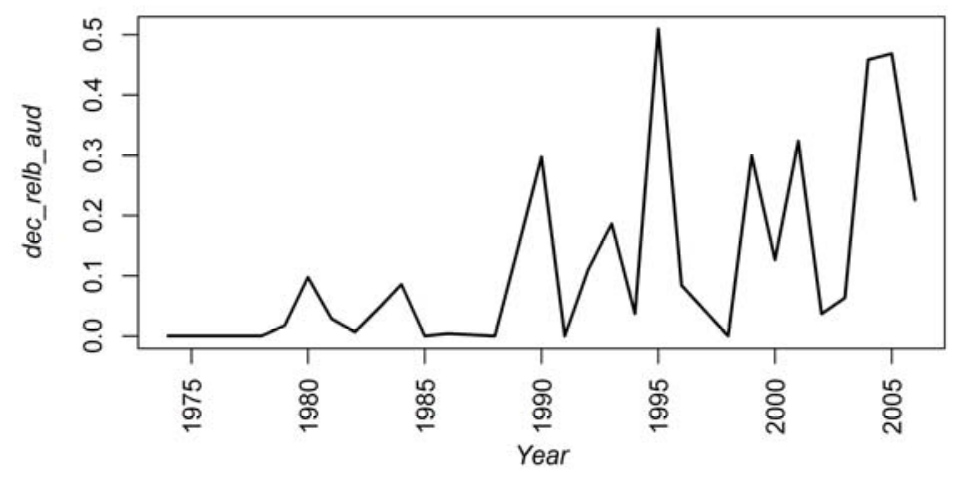

Figure 2:

Benchmark assessments of decreased reliability in proposed standards

The sample is based on 127 exposure drafts issued between 1973 and 2006. benchmark is an assessment that a proposed standard will decrease accounting reliability determined by two seasoned, independent research assistants.

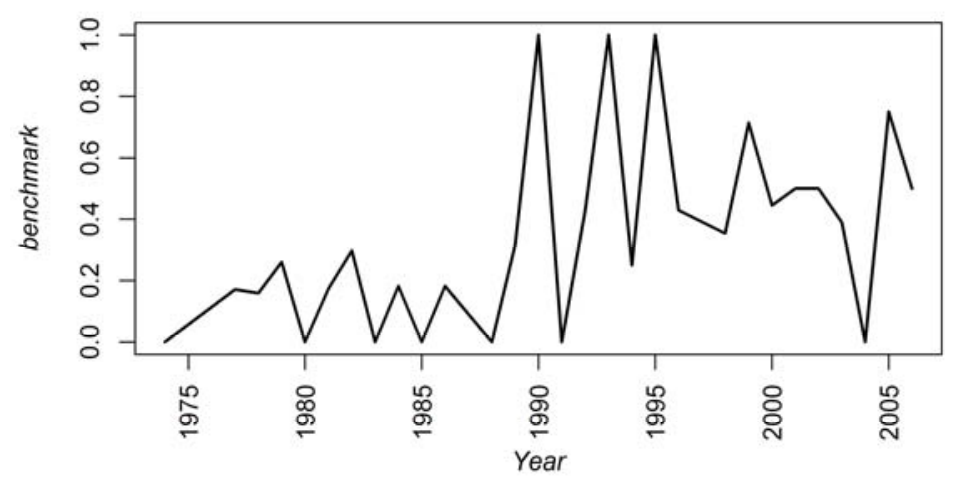




\section{Figure 3:}

\section{Civil suits filed against Big $\mathbf{N}$ auditors}

The sample is based on 127 exposure drafts issued between 1973 and 2006. civil lit represents a count of all civil litigation cases filed against Big $\mathrm{N}$ auditors in the twelve months preceding a given exposure draft, scaled by the total number of Compustat firms audited by Big $\mathrm{N}$ auditors in those twelve months.

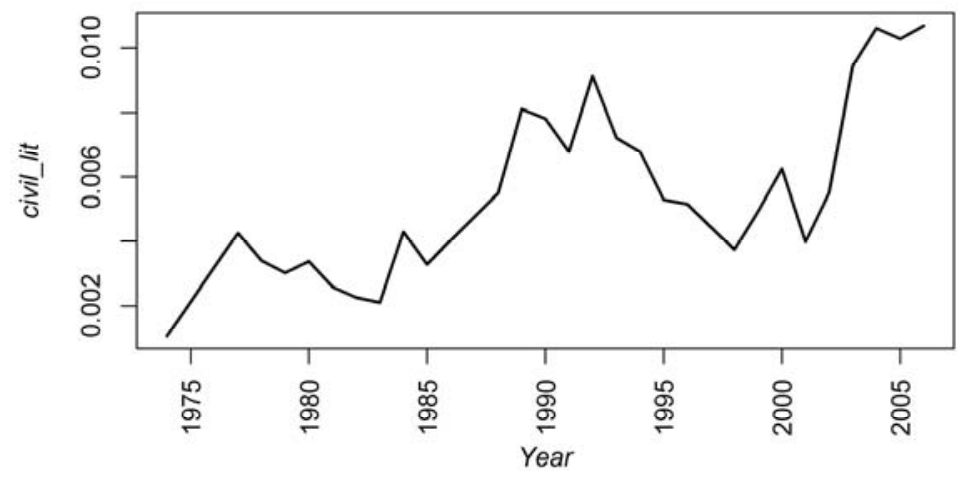

\section{Figure 4:}

\section{SEC Auditing and Accounting Enforcement Releases}

The sample is based on 127 exposure drafts issued between 1973 and 2006. aaers represents a count of auditing and accounting enforcement actions filed by the SEC in the twelve months preceding a given exposure draft, scaled by the total number Compustat firms in those twelve months.

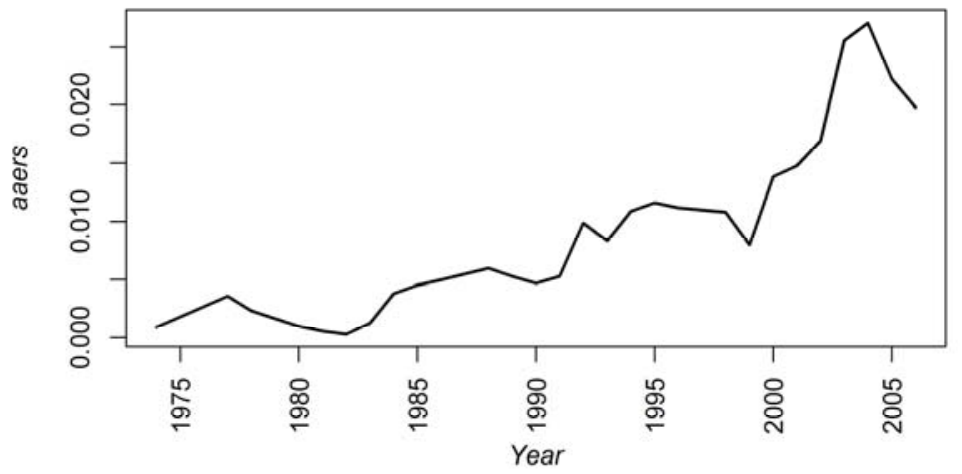




\section{Figure 5:}

\section{Client preferences for flexibility}

The sample is based on 127 exposure drafts issued between 1973 and 2006. flexibility is the first dimension of a principal component analysis of the following four variables, computed for each twelve-month period preceding a given exposure draft: the median total assets (normalized to 1973 dollars) of all firms that are clients of the Big $\mathrm{N}$ auditors; the median Tobin's q of such clients; the median operating cycle of such clients; and the median stock return volatility of such clients.

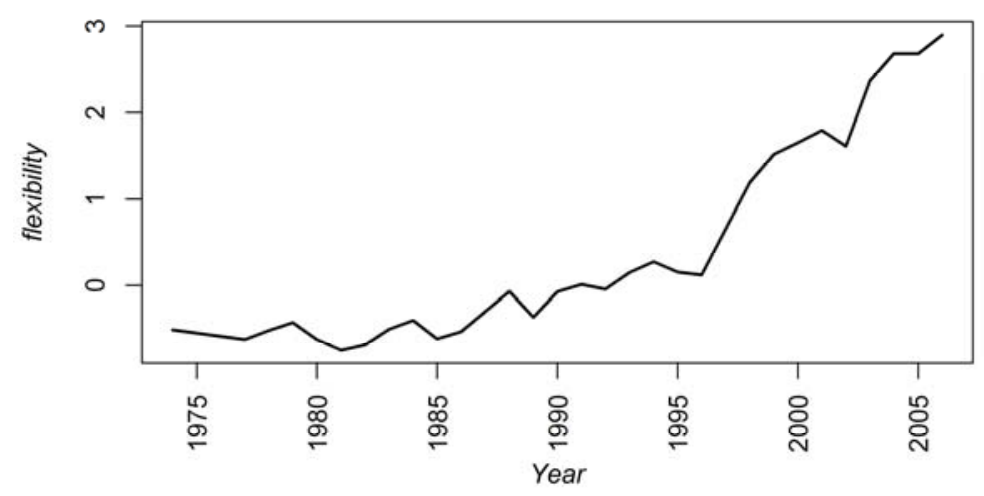

\section{Figure 6:}

\section{Number of comment letters filed}

The sample is based on 127 exposure drafts issued between 1973 and 2006. num_letters is the natural logarithm of the total number of comment letters filed on an exposure draft.

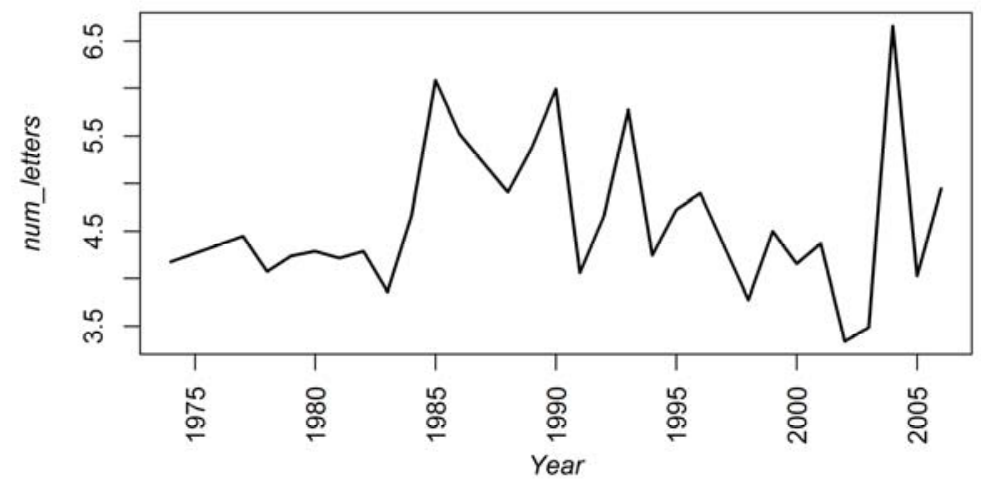




\section{Figure 7:}

Proportion of exposure drafts that increase the use of fair values

The sample is based on 127 exposure drafts issued between 1973 and 2006. fair_value is an indicator that takes the value one for exposure drafts determined by independent research assistants to increase the use of fair values.

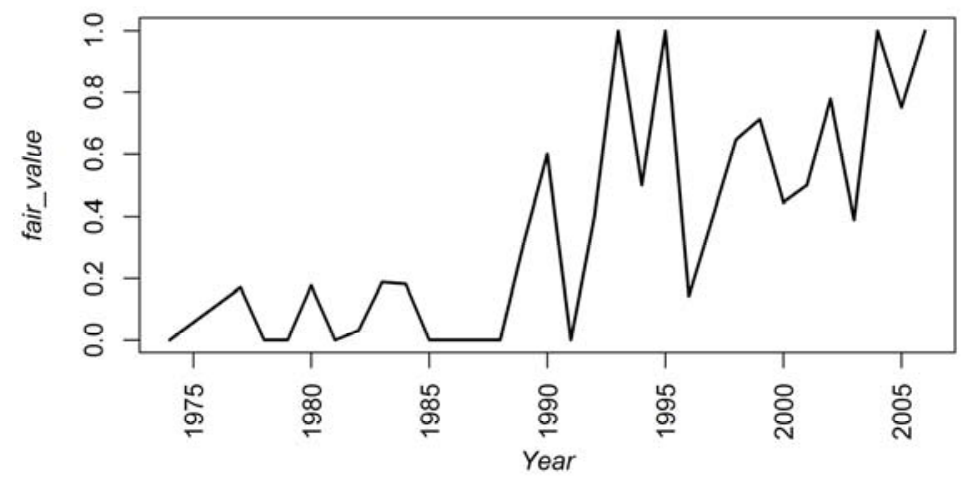

\section{Figure 8:}

\section{Proportion of FASB members most recently employed in financial services}

The sample is based on 127 exposure drafts issued between 1973 and 2006. pct_fin_fasb is an exposure-draft-level measure of the proportion of extant FASB members with most-recent former employment in investment banking or investment management.

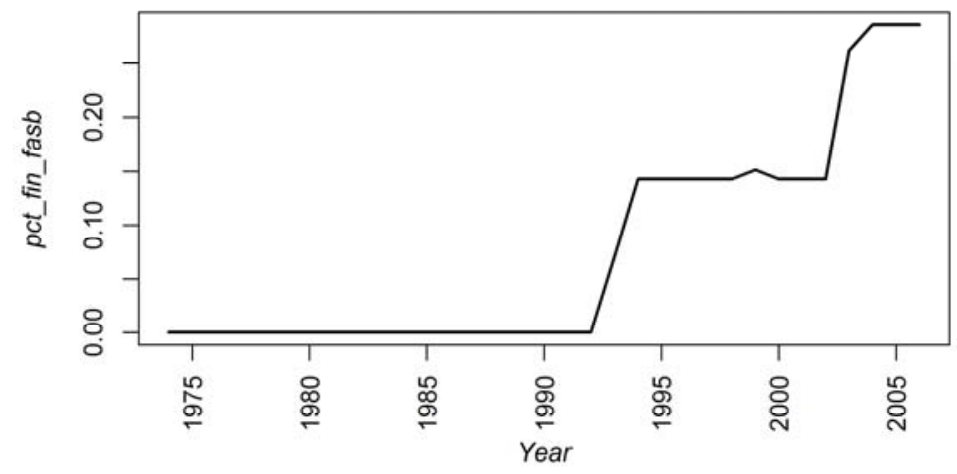




\section{Table 1:}

Description of the sample of Big $\mathbf{N}$ auditor comment letters and FASB exposure drafts
(A) Number of exposure drafts leading to SFAS, 1973-2006
(B) Less, exposure drafts with no comment letters by Big $\mathrm{N}$ auditors
22
(C) Initial sample of exposure drafts with Big $\mathrm{N}$ comment letters
(D) Number of Big $\mathrm{N}$ comment letters on exposure drafts in (C)
865
(E) Exposure drafts in (C) unavailable for manual assessment by
(F) Number of exposure drafts in the final sample
(G) Number of comment letters in the final sample 


\section{Table 2:}

Summary statistics for Big $\mathbf{N}$ auditor and benchmark assessments of decreased reliability

The sample is based on 737 Big N auditor comment letters on 127 distinct exposure drafts issued between 1973 and 2006. dec_relb_aud is the auditors' assessment that a proposed standard will decrease accounting reliability. benchmark is an assessment that a proposed standard will decrease accounting reliability determined by two seasoned, independent research assistants.

\begin{tabular}{lrrrrrr}
\hline Variable & n & Mean & Med & S.D. & Min & Max \\
\hline dec_relb_aud & 737 & 0.08 & 0.00 & 0.23 & 0.00 & 0.99 \\
benchmark & 737 & 0.28 & 0.00 & 0.45 & 0.00 & 1.00 \\
\hline
\end{tabular}




\section{Table 3:}

\section{Summary statistics for independent variables}

The sample is based on 737 Big $\mathrm{N}$ auditor comment letters on 127 distinct exposure drafts issued between 1973 and 2006. civil_lit represents a count of all civil litigation cases filed against Big $\mathrm{N}$ auditors in the twelve months preceding a given exposure draft, scaled by the total number of Compustat firms audited by Big $\mathrm{N}$ auditors in those twelve months. aaers represents a count of auditing and accounting enforcement actions filed by the SEC in the twelve months preceding a given exposure draft, scaled by the total number Compustat firms in those twelve months. flexibility is the first dimension of a principal component analysis of the following four variables, computed for each twelve-month period preceding a given exposure draft: the median total assets (normalized to 1973 dollars) of all firms that are clients of the Big N auditors; the median Tobin's q of such clients; the median operating cycle of such clients; and the median stock return volatility of such clients. industry_ED is an indicator identifying industryspecific exposure drafts. aud_specialization is an indicator identifying industry-dependent Big N auditors lobbying on industry-specific standards. num_letters is the natural logarithm of the total number of comment letters filed on an exposure draft. fair_value is an indicator that takes the value one for exposure drafts determined by independent research assistants to increase the use of fair values. pct fin_fasb is an exposure-draft-level measure of the proportion of extant FASB members with most-recent former employment in investment banking or investment management.

\begin{tabular}{rrrrrr}
\hline Variable & $\mathbf{n}$ & Mean & S.D. & Min & Max \\
\hline civil_lit & 737 & 0.005 & 0.002 & 0.001 & 0.011 \\
aaers & 737 & 0.006 & 0.007 & 0.000 & 0.027 \\
flexibility & 737 & 0.000 & 1.000 & -1.259 & 3.509 \\
industry_ED & 737 & 0.227 & 0.419 & 0.000 & 1.000 \\
aud_specialization & 737 & 0.085 & 0.280 & 0.000 & 1.000 \\
num_letters* & 737 & 176.6 & 508.5 & 4.0 & 6536 \\
fair_value & 737 & 0.236 & 0.425 & 0.000 & 1.000 \\
pct_fin_fasb & 737 & 0.049 & 0.085 & 0.000 & 0.286 \\
\hline
\end{tabular}

* For ease of interpretation, num_letters in this table is presented prior to the log transformation. 


\section{Table 4:}

\section{Big $\mathbf{N}$ auditor lobbying to manage their expected litigation and regulatory costs}

The sample is based on 737 Big N auditor comment letters on 127 distinct exposure drafts issued between 1973 and 2006. The dependent variable, dec_relb_aud, is the auditors' assessment that a proposed standard will decrease accounting reliability. benchmark is an assessment that a proposed standard will decrease accounting reliability determined by two seasoned, independent research assistants. civil_lit represents a count of all civil litigation cases filed against Big $\mathrm{N}$ auditors in the twelve months preceding a given exposure draft, scaled by the total number of Compustat firms audited by Big $\mathrm{N}$ auditors in those twelve months. aaers represents a count of auditing and accounting enforcement actions filed by the SEC in the twelve months preceding a given exposure draft, scaled by the total number Compustat firms in those twelve months. The notations $* * *$ and $* *$ denote statistical significance at the $1 \%$ and $5 \%$ levels, respectively, based on heteroskedastic cluster-robust standard errors.

\begin{tabular}{|c|c|c|c|c|c|}
\hline & (1) & (2) & & (3) & \\
\hline civil_lit & -27.12 & & & -36.11 & $* *$ \\
\hline civil_lit*benchmark & $206.14 * *$ & & & 152.89 & $* * *$ \\
\hline aaers & & 22.80 & $* *$ & 29.68 & $* *$ \\
\hline aaers*benchmark & & 99.15 & $* *$ & 80.07 & $* *$ \\
\hline Year fixed effects & Yes & Yes & & Yes & \\
\hline $\begin{array}{r}\text { Year fixed effects * } \\
\text { benchmark }\end{array}$ & Yes & Yes & & Yes & \\
\hline Std. errors cluster & ED & ED & & ED & \\
\hline $\mathrm{N}$ & 737 & 737 & & 737 & \\
\hline R-sq. & 0.39 & 0.41 & & 0.41 & \\
\hline
\end{tabular}




\section{Table 5:}

\section{Big $\mathbf{N}$ auditor lobbying to cater to clients' preferences for flexibility}

The sample is based on 737 Big N auditor comment letters on 127 distinct exposure drafts issued between 1973 and 2006. The dependent variable, dec_relb_aud, is the auditors' assessment that a proposed standard will decrease accounting reliability. benchmark is an assessment that a proposed standard will decrease accounting reliability determined by two seasoned, independent research assistants. flexibility is the first dimension of a principal component analysis of the following four variables, computed for each twelve-month period preceding a given exposure draft: the median total assets (normalized to 1973 dollars) of all firms that are clients of the Big $\mathrm{N}$ auditors; the median Tobin's q of such clients; the median operating cycle of such clients; and the median stock return volatility of such clients. industry_ED is an indicator identifying industry-specific exposure drafts. aud_specialization is an indicator identifying industry-dependent Big $\mathrm{N}$ auditors lobbying on industry-specific standards. num_letters is the natural logarithm of the total number of comment letters filed on an exposure draft. The notation $* *$ denotes statistical significance at the $5 \%$ level, based on heteroskedastic cluster-robust standard errors.

\begin{tabular}{|c|c|c|c|c|c|c|c|}
\hline & \multicolumn{2}{|l|}{ (1) } & \multirow[t]{2}{*}{ (2) } & \multicolumn{2}{|l|}{ (3) } & \multicolumn{2}{|l|}{ (4) } \\
\hline flexibility & -0.049 & $* *$ & & & & -0.047 & $* *$ \\
\hline flexibility*benchmark & -0.115 & & & & & -0.114 & \\
\hline industry_ED & & & -0.027 & & & -0.005 & \\
\hline aud_specialization & & & 0.080 & & & 0.068 & \\
\hline aud_specialization*benchmark & & & 0.003 & & & 0.007 & \\
\hline num_letters & & & & 0.011 & & 0.013 & \\
\hline num_letters*benchmark & & & & 0.095 & $* *$ & 0.098 & $* *$ \\
\hline Year fixed effects & Yes & & Yes & Yes & & Yes & \\
\hline $\begin{array}{r}\text { Year fixed effects } * \\
\text { benchmark }\end{array}$ & Yes & & Yes & Yes & & Yes & \\
\hline Std. errors cluster & ED & & ED & ED & & ED & \\
\hline $\mathrm{N}$ & 737 & & 737 & 737 & & 737 & \\
\hline R-sq. & 0.39 & & 0.41 & 0.41 & & 0.39 & \\
\hline
\end{tabular}




\section{Table 6:}

\section{Big $\mathbf{N}$ auditor lobbying and support for fair-value accounting}

The sample is based on 737 Big $\mathrm{N}$ auditor comment letters on 127 distinct exposure drafts issued between 1973 and 2006. The dependent variable, dec_relb_aud, is the auditors' assessment that a proposed standard will decrease accounting reliability. benchmark is an assessment that a proposed standard will decrease accounting reliability determined by two seasoned, independent research assistants. fair_value is an indicator that takes the value one for exposure drafts determined by independent research assistants to increase the use of fair values. pct_fin_fasb is an exposure-draft-level measure of the proportion of extant FASB members with most-recent former employment in investment banking or investment management. The notations *** and ** denote statistical significance at the $1 \%$ and $5 \%$ levels, respectively, based on heteroskedastic cluster-robust standard errors.

\begin{tabular}{|c|c|c|c|c|c|c|}
\hline & (1) & & $(2)$ & & (3) & \\
\hline fair_value & 0.194 & $* * *$ & & & 0.195 & $* * *$ \\
\hline fair_value*benchmark & -0.225 & $* *$ & & & -0.225 & $* * *$ \\
\hline pct_fin_fasb & & & 0.570 & & -0.111 & \\
\hline pct_fin_fasb ${ }^{*}$ benchmark & & & -3.038 & $* * *$ & -2.357 & $* * *$ \\
\hline Year fixed effects & Yes & & Yes & & Yes & \\
\hline $\begin{array}{r}\text { Year fixed effects * } \\
\text { benchmark }\end{array}$ & Yes & & Yes & & Yes & \\
\hline Std. errors cluster & ED & & ED & & ED & \\
\hline $\mathrm{N}$ & 737 & & 737 & & 737 & \\
\hline R-sq. & 0.41 & & 0.40 & & 0.42 & \\
\hline
\end{tabular}




\section{Table 7: \\ Consolidated analysis of Big $\mathbf{N}$ auditor lobbying}

The sample is based on 737 Big $\mathrm{N}$ auditor comment letters on 127 distinct exposure drafts issued between 1973 and 2006. The dependent variable, dec_relb_aud, is the auditors' assessment that a proposed standard will decrease accounting reliability. benchmark is an assessment that a proposed standard will decrease accounting reliability determined by two seasoned, independent research assistants. civil_lit represents a count of all civil litigation cases filed against Big $\mathrm{N}$ auditors in the twelve months preceding a given exposure draft, scaled by the total number of Compustat firms audited by Big $\mathrm{N}$ auditors in those twelve months. aaers represents a count of auditing and accounting enforcement actions filed by the SEC in the twelve months preceding a given exposure draft, scaled by the total number Compustat firms in those twelve months. flexibility is the first dimension of a principal component analysis of the following four variables, computed for each twelve-month period preceding a given exposure draft: the median total assets (normalized to 1973 dollars) of all firms that are clients of the Big $\mathrm{N}$ auditors; the median Tobin's q of such clients; the median operating cycle of such clients; and the median stock return volatility of such clients. industry_ED is an indicator identifying industry-specific exposure drafts. aud_specialization is an indicator identifying industry-dependent Big $\mathrm{N}$ auditors lobbying on industry-specific standards. num_letters is the natural logarithm of the total number of comment letters filed on an exposure draft. fair_value is an indicator that takes the value one for exposure drafts determined by independent research assistants to increase the use of fair values. pct_fin_fasb is an exposure-draft-level measure of the proportion of extant FASB members with most-recent former employment in investment banking or investment management. The notations ***, **, and * denote statistical significance at the $1 \%, 5 \%$, and $10 \%$ levels, respectively, based on heteroskedastic cluster-robust standard errors. 


\begin{tabular}{|c|c|c|}
\hline & $(1)$ & \\
\hline civil_lit & -43.51 & $* * *$ \\
\hline civil_lit*benchmark & 120.30 & $* *$ \\
\hline aaers & 14.92 & \\
\hline aaers*benchmark & 98.55 & $* * *$ \\
\hline flexibility & -0.048 & $* *$ \\
\hline flexibility*benchmark & -0.121 & \\
\hline industry_ED & -0.002 & \\
\hline aud_specialization & 0.069 & \\
\hline aud_specialization*benchmark & -0.005 & \\
\hline num_letters & -0.013 & \\
\hline num_letters*benchmark & 0.060 & \\
\hline fair_value & 0.212 & $* * *$ \\
\hline fair_value*benchmark & -0.221 & $*$ \\
\hline$p c t$ fin_fasb & 0.270 & \\
\hline pct_fin_fasb*benchmark & -2.910 & $* * *$ \\
\hline Year fixed effects & Yes & \\
\hline $\begin{array}{r}\text { Year fixed effects } * \\
\text { benchmark }\end{array}$ & Yes & \\
\hline Std. errors cluster & ED & \\
\hline $\mathrm{N}$ & 737 & \\
\hline R-sq. & 0.47 & \\
\hline
\end{tabular}




\section{Table 8:}

\section{Big $\mathbf{N}$ auditor lobbying across different litigation eras}

The sample is based on 737 Big N auditor comment letters on 127 distinct exposure drafts issued between 1973 and 2006. The dependent variable, dec_relb_aud, is the auditors' assessment that a proposed standard will decrease accounting reliability. The primary independent variable, benchmark, is an assessment that a proposed standard will decrease accounting reliability determined by two seasoned, independent research assistants. Era-average coefficients and heteroskedastic robust standard errors are obtained using a linear combination of annual values as detailed in Section 4.3. The notations $* * *$ and $* *$ denote statistical significance at the $1 \%$ and $5 \%$ levels, respectively.

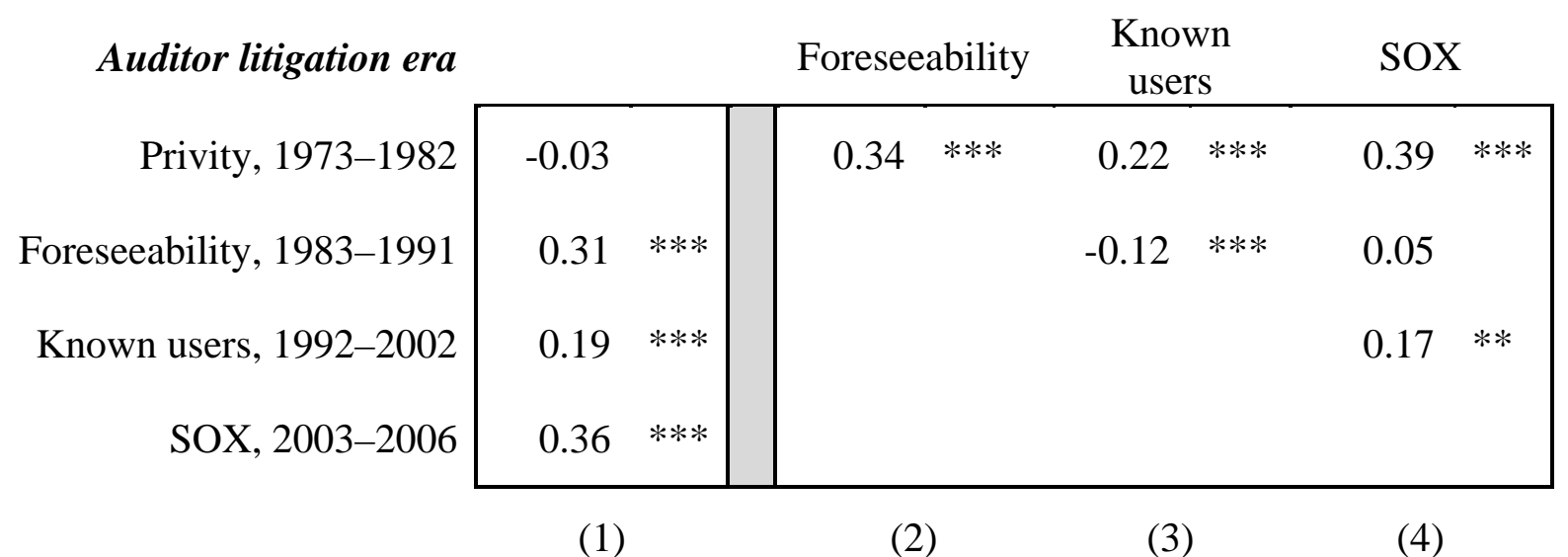




\section{Table 9:}

\section{Big $\mathbf{N}$ auditor lobbying across different oligopoly eras}

The sample is based on 737 Big N auditor comment letters on 127 distinct exposure drafts issued between 1973 and 2006. The dependent variable, dec_relb_aud, is the auditors' assessment that a proposed standard will decrease accounting reliability. The primary independent variable, benchmark, is an assessment that a proposed standard will decrease accounting reliability determined by two seasoned, independent research assistants. Era-average coefficients and heteroskedastic robust standard errors are obtained using a linear combination of annual values as detailed in Section 4.3. The notations $* * *$ and * denote statistical significance at the $1 \%$ and $10 \%$ levels, respectively.

Big $N$ oligopoly era

Big 6

Big5

Big4

\begin{tabular}{l|cc|}
\cline { 2 - 3 } Big 8, 1973-1989 & 0.09 & $* * *$ \\
Big 6, 1990-1998 & 0.14 & $* * *$ \\
Big 5, 1999-2002 & 0.24 & $* * *$ \\
Big 4, 2003-2006 & 0.36 & $* * *$ \\
\hline
\end{tabular}

(1)

(2)

(3)

(4) 